Cite this: Chem. Soc. Rev., 2012,41,6663-6683

\title{
Global air quality and climate $\dagger \ddagger$
}

\author{
Arlene M. Fiore, ${ }^{* a}$ Vaishali Naik, ${ }^{b}$ Dominick V. Spracklen, ${ }^{c}$ Allison Steiner ${ }^{d}$ \\ Nadine Unger, ${ }^{e}$ Michael Prather, ${ }^{f}$ Dan Bergmann, ${ }^{g}$ Philip J. Cameron-Smith, ${ }^{g}$ \\ Irene Cionni, ${ }^{h}$ William J. Collins, ${ }^{i}$ Stig Dalsøren, ${ }^{j}$ Veronika Eyring, ${ }^{k}$

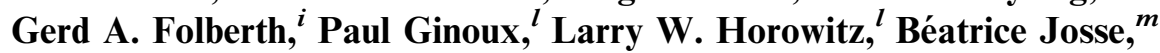 \\ Jean-François Lamarque, ${ }^{n}$ Ian A. MacKenzie, ${ }^{o}$ Tatsuya Nagashima, ${ }^{p}$ \\ Fiona M. O'Connor, ${ }^{i}$ Mattia Righi, ${ }^{k}$ Steven T. Rumbold, ${ }^{i}$ Drew T. Shindell, ${ }^{q}$ \\ Ragnhild B. Skeie, ${ }^{j}$ Kengo Sudo, ${ }^{r}$ Sophie Szopa, ${ }^{s}$ Toshihiko Takemura ${ }^{t}$ and \\ Guang Zeng ${ }^{u}$
}

Received 24th March 2012

DOI: $10.1039 / \mathrm{c} 2 \operatorname{cs} 35095 \mathrm{e}$

\begin{abstract}
Emissions of air pollutants and their precursors determine regional air quality and can alter climate. Climate change can perturb the long-range transport, chemical processing, and local meteorology that influence air pollution. We review the implications of projected changes in methane $\left(\mathrm{CH}_{4}\right)$, ozone precursors $\left(\mathrm{O}_{3}\right)$, and aerosols for climate (expressed in terms of the radiative forcing metric or changes in global surface temperature) and hemispheric-to-continental scale air quality. Reducing the $\mathrm{O}_{3}$ precursor $\mathrm{CH}_{4}$ would slow near-term warming by decreasing both $\mathrm{CH}_{4}$ and tropospheric $\mathrm{O}_{3}$. Uncertainty remains as to the net climate forcing from anthropogenic nitrogen oxide $\left(\mathrm{NO}_{x}\right)$ emissions, which increase tropospheric $\mathrm{O}_{3}$ (warming) but also increase aerosols and decrease $\mathrm{CH}_{4}$ (both cooling). Anthropogenic emissions of carbon monoxide (CO) and non- $\mathrm{CH}_{4}$ volatile organic compounds (NMVOC) warm by increasing both $\mathrm{O}_{3}$ and $\mathrm{CH}_{4}$. Radiative impacts from secondary organic aerosols (SOA) are poorly understood. Black carbon emission controls, by reducing the absorption of sunlight in the atmosphere and on snow and ice, have the potential to slow near-term warming, but uncertainties in coincident emissions of reflective (cooling) aerosols and poorly constrained cloud indirect effects confound robust estimates of net climate impacts. Reducing sulfate and nitrate aerosols would improve air quality and lessen interference with the hydrologic cycle, but lead to warming. A holistic and balanced view is thus needed to assess how air pollution controls influence climate; a first step
\end{abstract}

${ }^{a}$ Department of Earth and Environmental Sciences and Lamont-Doherty Earth Observatory of Columbia University, Palisades, NY, USA. E-mail: amfiore@ldeo.columbia.edu

${ }^{b}$ UCAR/Geophysical Fluid Dynamics Laboratory, NOAA, Princeton, NJ, USA

${ }^{c}$ School of Earth and Environment, University of Leeds, Leeds, UK

${ }^{d}$ Department of Atmospheric, Oceanic and Space Sciences, University of Michigan, Ann Arbor, MI, USA

${ }^{e}$ Yale School of Forestry and Environmental Studies, New Haven, CT, USA

${ }^{f}$ Department of Earth System Science, University of California, Irvine, CA, USA

${ }^{g}$ Lawrence Livermore National Laboratory, Livermore, CA, USA

${ }^{h}$ Agenzia nazionale per le nuove tecnologie, l'energia e lo sviluppo economico sostenibile (ENEA), Bologna, Italy

${ }^{i}$ Met Office, Hadley Centre, Exeter, UK

${ }^{j}$ CICERO, Center for International Climate and Environmental, Research-Oslo, Oslo, Norway

${ }^{k}$ Deutsches Zentrum für Luft- und Raumfahrt (DLR), Institut für Physik der Atmosphäre, Oberpfaffenhofen, Germany

${ }^{l}$ Geophysical Fluid Dynamics Laboratory, NOAA, Princeton, NJ, USA

${ }^{m}$ GAME/CNRM, Météo-France, CNRS - Centre National de Recherches Météorologiques, Toulouse, France

${ }^{n}$ National Center for Atmospheric Research, Boulder, CO, USA

${ }^{o}$ School of GeoSciences, The University of Edinburgh, UK

${ }^{p}$ National Institute for Environmental Studies, Tsukuba, Japan

${ }^{q}$ Goddard Institute for Space Studies, NASA, New York, NY, USA

${ }^{r}$ Nagoya University, Nagoya, Japan

${ }^{s}$ Laboratoire des Sciences du Climat et de l'Environnement LSCE-IPSL, CEA/CNRS/UVSQ, Gif-Sur-Yvette, France

${ }^{t}$ Research Institute for Applied Mechanics, Kyushu University, Fukuoka, Japan

${ }^{u}$ National Institute of Water and Atmospheric Research, Lauder, New Zealand

$\dagger$ Part of the atmospheric chemistry themed issue.

$\ddagger$ Electronic supplementary information (ESI) available. See DOI: 10.1039/c2cs35095e 
towards this goal involves estimating net climate impacts from individual emission sectors. Modeling and observational analyses suggest a warming climate degrades air quality (increasing surface $\mathrm{O}_{3}$ and particulate matter) in many populated regions, including during pollution episodes. Prior Intergovernmental Panel on Climate Change (IPCC) scenarios (SRES) allowed unconstrained growth, whereas the Representative Concentration Pathway (RCP) scenarios assume uniformly an aggressive reduction, of air pollutant emissions. New estimates from the current generation of chemistry-climate models with RCP emissions thus project improved air quality over the next century relative to those using the IPCC SRES scenarios. These two sets of projections likely bracket possible futures. We find that uncertainty in emission-driven changes in air quality is generally greater than uncertainty in climate-driven changes. Confidence in air quality projections is limited by the reliability of anthropogenic emission trajectories and the uncertainties in regional climate responses, feedbacks with the terrestrial biosphere, and oxidation pathways affecting $\mathrm{O}_{3}$ and $\mathrm{SOA}$.

\section{Introduction}

Air pollutants and their precursors can force the climate system by altering solar and terrestrial radiation budgets, and their distributions are in turn highly dependent upon regional climate. We focus here on two major global air pollutants, ozone $\left(\mathrm{O}_{3}\right)$ and aerosols (referred to interchangeably with particulate matter below) in the near-surface atmospheric boundary layer. Increases in surface $\mathrm{O}_{3}$ and particulate matter (with diameter $<2.5 \mu \mathrm{m}$, hereafter $\mathrm{PM}_{2.5}$ ) driven by human activities since the pre-industrial have been blamed for $0.7 \pm 0.3$ million annual respiratory mortalities and $3.5 \pm 0.9$ million annual cardiopulmonary mortalities, respectively. ${ }^{1}$ When considering strategies to abate air pollution and mitigate anthropogenic climate warming, policymakers face tradeoffs ${ }^{2}$ and synergies. ${ }^{3}$ For example, sulfate is a major component of $\mathrm{PM}_{2.5}$ pollution in many regions, but reducing sulfate for health reasons could lead to a rapid rise in surface temperatures (e.g., ref. 4 and 5), possibly at rates threatening the survival of some ecosystems. ${ }^{2}$ In the absence of emission changes, a warming climate may degrade air quality in many polluted regions, ${ }^{6,7}$ an impact that has been referred to as "a climate change penalty" on air quality. ${ }^{8}$ We review the current understanding of the interactions between air pollutants and climate, aiming to identify robust conclusions that may guide decision-making and to highlight critical knowledge gaps.

Any successful climate mitigation effort must address carbon dioxide $\left(\mathrm{CO}_{2}\right)$. The relatively short lifetimes of other radiatively active air pollutants and their precursors (days to weeks for $\mathrm{O}_{3}$ and aerosols, and approximately a decade for methane) implies that changes in their atmospheric abundances could induce rapid climate responses in the next few decades. ${ }^{9}$ We thus refer to these species as "Near-Term Climate Forcers" (NTCFs). Many studies reviewed here compare climate impacts of different NTCFs by estimating radiative forcing (RF). RF is defined by the Intergovernmental Panel on Climate Change (IPCC) as the change in net radiative flux at the tropopause, after allowing stratospheric temperatures to adjust (note that other RF estimates allow other fast time scale adjustments), induced by a change in atmospheric abundance or distribution of a radiatively active species, typically expressed for present day relative to the preindustrial. ${ }^{10}$ The equilibrium global mean surface temperature response corresponds to the annual globally averaged RF after accounting for the climate sensitivity, which encompasses the feedbacks in the climate system. Determining relative climate impacts from different species by comparing RFs assumes that climate responses (e.g., temperature, precipitation, circulation changes) scale accordingly. This assumption is not well-suited to the short-lived, heterogenous distributions of air pollutants and their precursors (except for the wellmixed greenhouse gas $\mathrm{CH}_{4}$ ) which vary in their forcing efficacy. ${ }^{11,12}$ A major advance in recent years is the incorporation of interactive chemistry into general circulation models (GCMs), which allows for the direct examination of climate responses to air pollutants and their precursors, and some of the chemistry-climate interactions ${ }^{13}$ in Table 1 . Below, we review this recent work as well as studies considering only RF from air pollutants.

The interactions between air pollutants and climate are often studied in the context of future emission scenarios. For projecting the future evolution of air quality under climate change, the most widely used emission trajectories to date are those described in the Special Report on Emission Scenarios (SRES). ${ }^{14}$ A newly developed set of scenarios, the Representative Concentration Pathways (RCPs), is currently in use for ongoing international, multi-model activities in support of the upcoming IPCC Fifth Assessment Report (AR5). The RCP scenarios are described in detail and contrasted with the SRES scenarios in several recent publications. ${ }^{15-22}$ All RCPs assume aggressive air pollution abatement measures (Fig. 1) and correspondingly large decreases in $\mathrm{PM}$ and $\mathrm{O}_{3}$ precursors globally. ${ }^{17,23}$ Exceptions include ammonia $\left(\mathrm{NH}_{3}\right)$, which increases in nearly all scenarios and $\mathrm{CH}_{4}$, which ranges from a $30 \%$ decrease to a more than doubling by 2100 (Fig. 1). We emphasize that the assumption of aggressive air pollution measures implemented globally is a major caveat in the RCP-based projections, as the small range of possible air pollutant emission trajectories across the RCPs may not represent the true uncertainty in emission pathways.

In Section 2, we review the literature on climate responses to emissions of air pollutants and their relevant precursors from anthropogenic sources and the terrestrial biosphere. Section 3 focuses on the processes by which changes in climate may influence air quality. Section 4 reviews projections for air quality over the next century, including changes driven by climate and emissions under a suite of scenarios. We end in Section 5 by discussing critical uncertainties and promising new directions targeting these knowledge gaps. 
Table 1 Impacts of temperature-driven pathways on surface $\mathrm{O}_{3}$ and PM over land, adapted from Table 1 of Jacob and Winner ${ }^{7}$ and Fig. 2 of Isaksen et $_{\text {al. }}{ }^{13}$

\begin{tabular}{|c|c|c|c|c|}
\hline Process & $\begin{array}{l}\text { Level of confidence that warmer } \\
\text { climate leads to increase }^{a}\end{array}$ & $\begin{array}{l}\text { Impact of increase in } \\
\text { process on } \mathrm{PM}^{b}\end{array}$ & $\begin{array}{l}\text { Impact of increase in } \\
\text { process on } \mathrm{O}_{3}^{b, c}\end{array}$ & Example references \\
\hline Non- $\mathrm{CH}_{4}$ BVOC emissions & Low & + & ? B, LR & $\begin{array}{l}6,13,54,205,325,346,349 \\
132,134,350\end{array}$ \\
\hline Wildfires & Medium & ++ & $+\mathrm{B}$ ?LR & $200,201,204,229,254,351,352$ \\
\hline $\mathrm{CH}_{4}$ from wetlands & Medium & $*(-)$ & $++\mathrm{B}$ & $13,56,353$ \\
\hline Dust & Low & ++ & $-\mathrm{LR}$ & $249,250,354-356$ \\
\hline Soil $\mathrm{NO}_{x}$ & Medium & * & $+\mathrm{B}, \mathrm{LR}$ & 13 \\
\hline STE of $\mathrm{O}_{3}$ & Medium & $*$ & $++\mathrm{B}$ & $13,238,320,357$ \\
\hline Lightning $\mathrm{NO}_{x}$ & Low & $*(+)$ & $++\mathrm{B}$ & $5,13,320,357-359$ \\
\hline Dry deposition & Low & $?$ & $--\mathrm{LR}, \mathrm{B}$ & $13,188,199,357$ \\
\hline Humidity & High & + & $--\mathrm{B}=\mathrm{LR}$ & $7,228,234,357$ \\
\hline Regional stagnation & Medium & ++ & $++\mathrm{LR}$ & $7,190,195,360$ \\
\hline Wind speed & Low & - & $-\mathrm{LR}$ & 7,361 \\
\hline Mixing depth & Low & -- & $=\mathrm{LR}$ & 7,361 \\
\hline Cloud cover & Low & - & $-\mathrm{LR}$ & 7 \\
\hline Precipitation & Low & -- & $=\mathrm{LR}$ & 7,361 \\
\hline
\end{tabular}
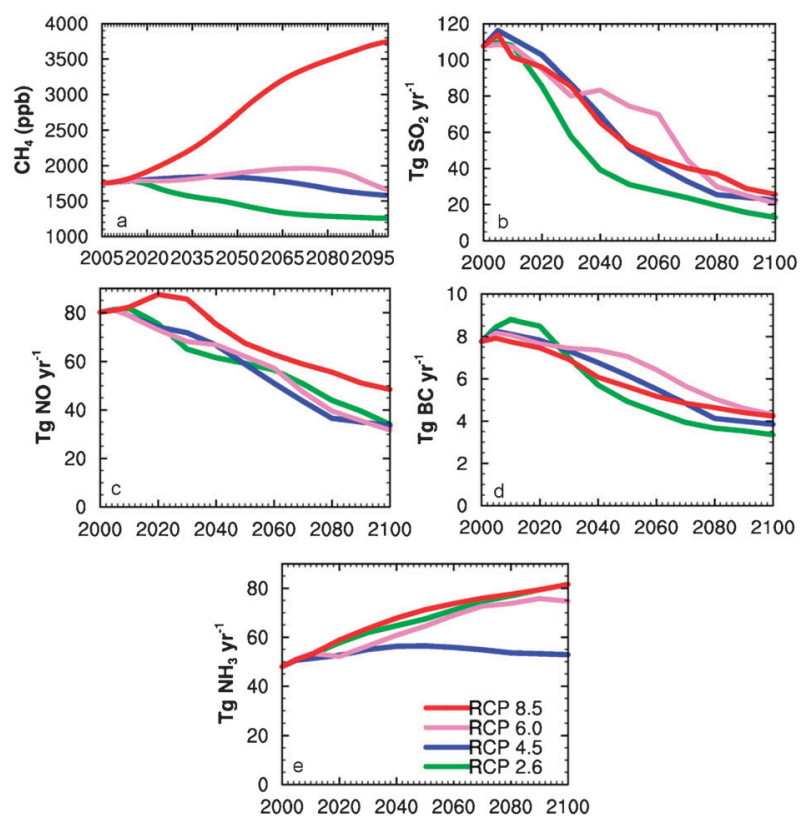

Fig. 1 Future evolution of (a) $\mathrm{CH}_{4}$ abundance and selected global emissions of air pollutants and precursors, (b) $\mathrm{SO}_{2}$, (c) $\mathrm{NO}$, (d) $\mathrm{BC}$, and (e) $\mathrm{NH}_{3}$, from anthropogenic plus biomass burning sources combined, under the RCP scenarios. ${ }^{16-18}$

\section{Sensitivity of climate to changes in air pollutant emissions}

We review the literature describing climate responses to changes in emissions of $\mathrm{O}_{3}$ precursors (Section 2.1), and aerosols and their precursors (Section 2.2). Understanding the climate responses to the particular mix of pollutant plus greenhouse gas sources from individual anthropogenic emission sectors (Section 2.3) is particularly relevant for policy decisions targeting controls on specific human activities.
We briefly highlight the potential for emissions from the terrestrial biosphere to respond to changing pollution levels and climate, and thereby further change air quality (Section 2.4). Biospheric feedbacks to climate have been addressed recently. ${ }^{24}$ Throughout this section, we report RFs from pre-industrial to present-day as reported in the literature. Individual studies vary in their choice of base year for both pre-industrial and present-day but this is unlikely to be a major contribution to the range of reported RFs.

\subsection{Ozone $\left(\mathrm{O}_{3}\right)$ precursors}

The increase in tropospheric $\mathrm{O}_{3}$ from pre-industrial to presentday driven by human activities ${ }^{25}$ has led to a positive climate forcing $\left(+0.35_{-0.1}^{+0.3} \mathrm{~W} \mathrm{~m}^{-2}\right)^{10}$ and substantial increases in $\mathrm{O}_{3}$ RF are estimated for the next century with the SRES scenarios. ${ }^{26}$ Emissions of $\mathrm{O}_{3}$ precursors, particularly nitrogen oxides $\left(\mathrm{NO}_{x}\right)$ and volatile organic compounds (VOC) also produce secondary aerosols and thereby a negative climate forcing, though this aerosol RF is poorly quantified relative to the $\mathrm{O}_{3} \mathrm{RF}^{27} \mathrm{We}$ discuss below the role of specific $\mathrm{O}_{3}$ precursor emissions, with a strong emphasis on the role of $\mathrm{CH}_{4}$, which has received growing attention in recent years as a means to address jointly air pollution and climate goals. ${ }^{3,28-30}$ The dominant $\mathrm{CH}_{4}$ sink occurs through oxidation by the hydroxyl radical $(\mathrm{OH})$ in the troposphere, which leads to a unique sensitivity of this greenhouse gas to air pollutants and their precursors. Indirect RFs from $\mathrm{O}_{3}$ precursors can occur via precursor-induced changes in oxidant concentrations, which can alter aerosol burdens; similarly, changes in aerosol burdens may alter $\mathrm{O}_{3}$ concentrations. ${ }^{27,31,32}$ An additional, poorly quantified, indirect RF occurs when high surface $\mathrm{O}_{3}$ concentrations damage vegetation and interfere with the carbon and hydrologic cycles. ${ }^{33,34}$

Nitrogen oxides $\left(\mathbf{N O}_{x}\right)$. As $\mathrm{NO}_{x}$ levels are sufficiently low in much of the troposphere, increases in anthropogenic $\mathrm{NO}_{x}\left(\mathrm{NO}+\mathrm{NO}_{2}\right)$ raise global average tropospheric $\mathrm{O}_{3}$ 
levels (e.g., ref. 35), thereby exerting a positive climate forcing. This positive forcing may be offset by an accompanying negative forcing due to lower $\mathrm{CH}_{4}$ abundances, because increasing $\mathrm{NO}_{x}$ enhances tropospheric $\mathrm{OH}$ and reaction with $\mathrm{OH}$ is the primary $\mathrm{CH}_{4}$ loss pathway in the atmosphere. ${ }^{36}$ The net RF of these opposing influences on the climate system depends upon the emission location and season, with surface anthropogenic $\mathrm{NO}_{x}$ emissions generally leading to net cooling but aircraft $\mathrm{NO}_{x}$ aloft leading to small net warming. ${ }^{37-43}$ Consideration of gas-aerosol interactions suggests that global increases in $\mathrm{NO}_{x}$ emissions may exert a greater negative forcing by enhancing sulfate burdens via increased oxidant levels. ${ }^{44}$ The aerosol response, however, is not robust across models ${ }^{27}$ and carbon cycle impacts from $\mathrm{O}_{3}$ exposure ${ }^{34}$ may be large enough to compensate for negative aerosol forcings.

Carbon monoxide (CO) and non-methane volatile organic compounds (NMVOC). Increases in CO and in global anthropogenic NMVOC lead unambiguously to additional positive climate forcing by raising both tropospheric $\mathrm{O}_{3}$ and $\mathrm{CH}_{4}$ abundances through a reduction in $\mathrm{OH}^{28,34,41,42,45,46}$ Individual anthropogenic NMVOC, however, can lead to secondary organic aerosol and an associated negative forcing. ${ }^{47}$ Gasaerosol interactions may augment this positive forcing by decreasing sulfate burdens. ${ }^{27,44}$ Projected decreases in these species under the RCPs ${ }^{17}$ would thus help to mitigate climate warming.

In contrast, the impact of biogenic VOC (BVOC) emissions on climate is highly uncertain. BVOC include a broad suite of carbon compounds emitted naturally from vegetation, including isoprene $\left(\mathrm{C}_{5} \mathrm{H}_{8}\right)$, monoterpenes $\left(\mathrm{C}_{10}\right.$ compounds), sesquiterpenes $\left(\mathrm{C}_{15}\right.$ compounds), and a large number of oxygenated VOC (e.g., methanol, ethanol, acetaldehyde, and methylbutenol). These emissions contribute approximately two-thirds of the non-methane VOC budget at the regional and global scale ${ }^{48}$ and the terpenoid compounds (isoprene and monoterpenes) are typically more reactive than many anthropogenic VOC. ${ }^{49}$ BVOC oxidation can contribute to $\mathrm{O}_{3}$ formation when $\mathrm{NO}_{x}$ is present. ${ }^{50,51}$ BVOC also alter global oxidant levels and thereby impact $\mathrm{CH}_{4}$ abundances. ${ }^{52}$ The magnitude and sign of the net climate influence, however, is uncertain given incomplete knowledge of BVOC oxidation chemistry and corresponding $\mathrm{OH}$ changes, particularly in low- $\mathrm{NO}_{x}$ regions of the atmosphere ${ }^{53,54}$ as discussed further in Section 5.

Methane $\left(\mathbf{C H}_{4}\right)$. Although not a direct air pollutant, $\mathrm{CH}_{4}$ oxidation in the presence of $\mathrm{NO}_{x}$ enhances global tropospheric $\mathrm{O}_{3}{ }^{35,55,56}$ From pre-industrial to present, the RF from the more-than-doubling of the atmospheric $\mathrm{CH}_{4}$ abundance is estimated to be $+0.48 \pm 0.05 \mathrm{~W} \mathrm{~m}^{-2}$, second after $\mathrm{CO}_{2}$ in terms of anthropogenic RF from greenhouse gases. ${ }^{10}$ An estimate of the net RF associated with the preindustrial-topresent growth in $\mathrm{CH}_{4}$ emissions includes the impact of $\mathrm{CH}_{4}$ on tropospheric $\mathrm{O}_{3}$, stratospheric water vapor, and aerosols. From this "emission-based view", $\mathrm{RF}$ from $\mathrm{CH}_{4}$ almost doubles from the abundance-based estimate to $0.8-1.0 \mathrm{~W} \mathrm{~m}^{-2} \cdot{ }^{44,45}$ The high end of the range includes the indirect influence of changes in oxidant chemistry on sulfate aerosol, where more $\mathrm{CH}_{4}$ leads to less $\mathrm{OH}$ and correspondingly less cooling via sulfate aerosol.

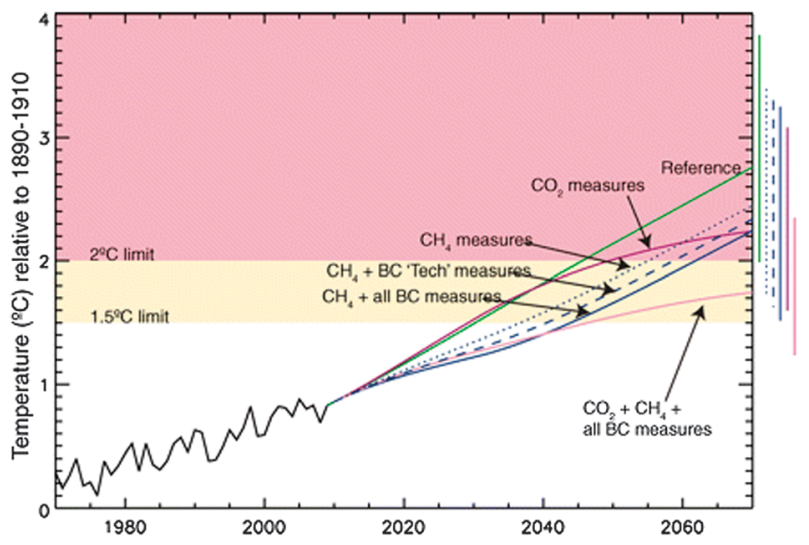

Fig. 2 Observed temperature anomaly through $2009^{362}$ and projected temperature anomaly under various scenarios, all relative to the 1890-1910 mean. Results for future scenarios are the central values from analytic equations estimating the response to forcings calculated from composition-climate modeling and literature assessments (see online material of Shindell et $\mathrm{al}^{3}{ }^{3}$ ). The rightmost bars give 2070 ranges, including uncertainty in radiative forcing and climate sensitivity. A portion of the uncertainty is systematic, so statistically significant differences between scenarios may still occur even with overlapping ranges (for example, if climate sensitivity is large, it is large regardless of the scenario, so all temperatures would be toward the high end of their ranges; see www.giss.nasa.gov/staff/dshindell/ Sci2012). From Shindell et al. ${ }^{3}$ (their Fig. 1). Reprinted with permission from AAAS.

A multi-model study, however, suggests a smaller sensitivity of aerosols to oxidant changes. ${ }^{27}$ Furthermore, the net RF due to increases in $\mathrm{CH}_{4}$ emissions since pre-industrial times has been partially offset by increases in $\mathrm{NO}_{x}$ emissions (which decrease $\mathrm{CH}_{4}$ by increasing global $\mathrm{OH}$ ). Scenarios for the 21 st century indicate a wide range of possible $\mathrm{CH}_{4}$ abundances (Fig. 1; Nakicenovic et al. ${ }^{14}$ ) and numerous abatement opportunities could lessen future $\mathrm{CH}_{4}$ RF. ${ }^{29,57-59}$ The recent WMO/UNEP report $^{30}$ estimates a $0.2-0.4 \mathrm{~K}$ decrease by 2050 relative to a reference emission scenario if a defined set of $\mathrm{CH}_{4}$ control technologies were implemented worldwide by 2030 , corresponding to a $24 \%$ decline in anthropogenic $\mathrm{CH}_{4}$ emissions relative to 2010 levels (Fig. 2; see also Shindell et al. $^{3}$ ).

Much uncertainty remains in our understanding of the contributions from specific source sectors to $\mathrm{CH}_{4}$ emissions, ${ }^{60}$ the underlying factors contributing to recent observed trends (e.g., ref. 61-63), and in feedbacks from the biosphere. ${ }^{13}$ Although these uncertainties limit confidence in accurately projecting the future evolution of $\mathrm{CH}_{4}$, it is clear that decreasing atmospheric $\mathrm{CH}_{4}$ would slow near-term warming, due to its stronger climate impact on the 20 year (versus 100 year) time frame, which could help to slow Arctic sea ice loss over the next few decades. ${ }^{64}$ Reducing $\mathrm{CH}_{4}$ would also decrease tropospheric $\mathrm{O}_{3}$, including the baseline $\mathrm{O}_{3}$ levels in surface air, thereby lessening the adverse impacts on vegetation and human health. ${ }^{28,29,59,65-69}$

\subsection{Aerosols}

Atmospheric aerosols impact climate in numerous ways (e.g., Isaksen et $\left.a l .{ }^{13}\right)$. Briefly, aerosols scatter and absorb shortwave 
and longwave radiation, known as the aerosol direct effect. ${ }^{70}$ Aerosols can also alter the properties of clouds through indirect effects (by affecting cloud microphysics), ${ }^{71}$ the semi-direct effect (where aerosol absorption affects temperature structure), ${ }^{72}$ and cloud absorption effects (from absorbing aerosol inclusions within or interstitially between hydrometeors). ${ }^{73}$ When absorbing aerosols (i.e. BC and potentially dust) are deposited onto snow and ice surfaces, they reduce surface albedo, which amplifies the positive RF. In addition, deposition of aerosols and their dissolved nutrients to the biosphere (land and ocean) may modify biogeochemical processes causing further changes to climate. ${ }^{74}$ It is unlikely that these effects add linearly.

Anthropogenic aerosol. Anthropogenic aerosol consists mainly of sulfate, nitrate, ammonium, black carbon (BC) and organic carbon (OC). These aerosol components interact with radiation in different ways depending on size and composition and contribute either a cooling or a warming forcing on climate. The AR4 IPCC report ${ }^{10}$ estimated that the net aerosol direct forcing from all anthropogenic components is likely to be a cooling with a best estimate of $-0.5 \pm 0.4 \mathrm{~W} \mathrm{~m}^{-2}$. Myhre et $a l^{75}$ used a combination of models and satellite observations to estimate the direct $\mathrm{RF}$ at $-0.35 \mathrm{~W} \mathrm{~m}^{-2}$ whereas Bellouin et $a l^{76}$ used satellite observations to estimate $-0.65 \mathrm{~W} \mathrm{~m}^{-2}$. Myhre ${ }^{77}$ report a best estimate for aerosol direct $\mathrm{RF}$ of $-0.3 \mathrm{~W} \mathrm{~m}^{-2}$ after reconciling divergent estimates from modeling and observational approaches by accounting for differences in cloud-masked forcing and changes over the last century in bulk aerosol optical properties. Sulfate, nitrate and OC aerosol scatter radiation with direct aerosol RFs estimated as $-0.4 \mathrm{~W} \mathrm{~m}^{-2},-0.1 \mathrm{~W} \mathrm{~m}^{-2}$ and $-0.05 \mathrm{~W} \mathrm{~m}^{-2}$ respectively. ${ }^{10} \mathrm{BC}$ absorbs solar and infrared radiation resulting in a positive aerosol direct effect that is estimated to be between +0.25 and $+0.44 \mathrm{~W} \mathrm{~m}^{-2}$ in model studies ${ }^{78}$ but potentially as large as $+0.9 \mathrm{~W} \mathrm{~m}^{-2}$ when constrained by observations. ${ }^{79,80}$ A multi-model assessment by Koch et al. ${ }^{81}$ shows that global models underestimate observed aerosol absorption optical depth (AAOD); scaling model AAOD to match observations resulted in $\mathrm{BC}$ multi-model average direct effect of $+0.55 \mathrm{~W} \mathrm{~m}^{-2}$. The absorption effect of $\mathrm{BC}$ in liquid cloud droplets may cause an additional $\mathrm{BC} \mathrm{RF}$ of $+0.1 \pm 0.4 \mathrm{~W} \mathrm{~m}^{-2} .{ }^{82}$

The impact of anthropogenic aerosol on clouds is more uncertain. The first aerosol indirect effect, also known as the cloud albedo effect, was estimated by the IPCC AR4 to be $-0.7 \mathrm{~W} \mathrm{~m}^{-2}$ (range -0.3 to $-1.8 \mathrm{~W} \mathrm{~m}^{-2}$ ). ${ }^{10}$ Quaas et al. ${ }^{83}$ used satellite data to estimate a smaller cloud albedo effect of $-0.2 \mathrm{~W} \mathrm{~m}^{-2}$, potentially suggesting that models may be overestimating the effect. However, a more recent multi-model estimate $^{84}$ linked to satellite observations quantified the aerosol indirect effect as $-0.7 \pm 0.45 \mathrm{~W} \mathrm{~m}^{-2}$. Very little is known on the contribution of different aerosol components to the aerosol indirect effect. While several studies have quantified the cloud albedo radiative effect of BC-containing particles, ${ }^{82,85-89}$ the sign of the cloud forcing is model-dependent and varies with the $\mathrm{BC}$ to $\mathrm{OC}$ mass ratio, the size of emitted particles, and the magnitude of the emission change.

Absorbing aerosols also impact climate after deposition to bright surfaces. In particular, BC causes additional warming of climate after deposition onto snow and ice surfaces by reducing the albedo of snow. ${ }^{90}$ Flanner et al. ${ }^{91}$ estimate that the snow-albedo forcing and associated feedbacks from all anthropogenic BC emissions result in global warming (annual mean temperature) of between 0.1 and $0.15 \mathrm{~K}$, while Jacobson ${ }^{92}$ finds that fossil and biofuel sources alone result in a warming of between 0.03 and $0.11 \mathrm{~K}$ through this effect.

The overall effect of anthropogenic aerosol is likely to be a cooling impact on climate. The IPCC AR4 estimated a total forcing of $-1.2 \mathrm{~W} \mathrm{~m}^{-2}$ from anthropogenic aerosol, partly offsetting the warming of $2.6 \mathrm{~W} \mathrm{~m}^{-2}$ from long-lived greenhouse gases. ${ }^{10}$ These estimates do not include aerosol-induced changes to biogeochemical cycles, which were recently estimated to be $-0.5 \pm 0.4 \mathrm{~W} \mathrm{~m}^{-2} \cdot{ }^{74}$ Uncertainty in the magnitude of the aerosol cooling leads to large uncertainties in projections of future climate change (e.g., ref. 93 and 94). Removal of this cooling influence due to air pollution abatement policies is expected to enhance future warming. ${ }^{95-98}$

The strong warming due to the direct effect and snowalbedo effect of $\mathrm{BC}$ imply that $\mathrm{BC}$ emission reductions could yield a short-term climate benefit. ${ }^{99-105}$ Models indicate that the Arctic is particularly sensitive to BC forcing. ${ }^{91,101,106}$ In particular, Flanner et al. ${ }^{107}$ find that deposition of $\mathrm{BC}$ and $\mathrm{OC}$ and the subsequent snow/ice albedo feedback induces $95 \%$ as much springtime snow cover loss over Eurasia as anthropogenic carbon dioxide. The combustion sources that emit BC, also emit other aerosol components that tend to cool climate, principally OC, so the net climate impact of emission controls is uncertain. Ramanathan and Carmichael $^{80}$ suggest that elimination of $\mathrm{BC}$ sources would reduce global surface temperatures by 0.5 to $1 \mathrm{~K}$. Shindell et $\mathrm{al}^{3}{ }^{3}$ simulated the effect of implementing a range of air quality measures that control the emissions of $\mathrm{BC}$-containing particles and $\mathrm{O}_{3}$ precursor species and estimate $0.19 \mathrm{~K}$ avoided warming by 2050 . They found that reducing $\mathrm{BC}$ emissions resulted in greater reductions in warming from the semi-direct effect than reductions in cooling from the indirect effect, although they note that the magnitude of these different effects is model dependent. In contrast, Leibensperger et al. ${ }^{108,109}$ found little warming due to BC over the US and suggested that $\mathrm{BC}$ emission controls in the US have little climate mitigation potential. The large uncertainty of the net impact of $\mathrm{BC}$ mitigation on surface temperatures reflects uncertainty in co-emitted species as well as cloud feedbacks. ${ }^{86-88,110}$

Regional temperature responses to aerosol forcings have been examined in a few studies. One study suggests that reductions in sulfate emissions alongside increases in $\mathrm{BC}$ emissions have contributed to some of the recent warming observed in the Arctic. ${ }^{111}$ Leibensperger et al. ${ }^{109}$ found that direct RF from anthropogenic aerosol peaked in 1970-1990 at $-2 \mathrm{~W} \mathrm{~m}^{-2}$ over the eastern US where it cooled annual mean temperatures over the central and eastern United States by 0.5-1 ${ }^{\circ} \mathrm{C}$. By 2010 , the forcing declined to $-1.2 \mathrm{~W} \mathrm{~m}^{-2}$ due mainly to decreasing $\mathrm{SO}_{2}$ emissions. They further suggested that U.S. anthropogenic aerosols are currently sufficiently low that future air quality improvements projected to occur over the period 2010-2050 will result in minimal warming $\left(0.1^{\circ} \mathrm{C}\right)$ over the United States. ${ }^{108}$ Mickley et al. ${ }^{112}$ calculated that complete removal of US anthropogenic aerosol sources would increase annual mean temperatures in the eastern US by $0.4-0.6{ }^{\circ} \mathrm{C}$, 
with larger increases of $1-2{ }^{\circ} \mathrm{C}$ during summertime heat waves due to feedbacks with soil moisture and low cloud cover. Similar feedbacks, including through fog reduction, have also been identified over Europe. ${ }^{113-115}$

Aerosols may alter regional atmospheric circulation patterns, ranging from shifts in the width of the tropics, Arctic Oscillation phasing, monsoons, jet locations, and associated precipitation. $^{80,108,116-121}$ Absorbing aerosols are possibly more potent at altering circulation patterns than $\mathrm{CO}_{2}$ and scattering aerosols. ${ }^{122-125}$ Observed drying trends over Africa, South Asia and northern China over the past decades have been partially attributed to anthropogenic aerosol forcing (e.g., ref, 80, 117, 126 and 127), suggesting that aerosol decreases in these regions over the next century would reverse these trends. Precipitation responses to changes in aerosol optical depth, anthropogenic aerosols, and specific fuel emissions sectors have been documented in several modeling studies (e.g., ref. 5, 31 and 128). Some studies have noted that the sign of the precipitation response to $\mathrm{BC}$ depends on the BC vertical distribution ${ }^{122,129}$ although this is poorly constrained in current models. ${ }^{81,130}$ Shindell et al. ${ }^{131}$ point out that controlling anthropogenic aerosols should restore disrupted regional precipitation patterns and consideration of this additional climate response may offset some of the adverse effects of the temperature rise induced by removing anthropogenic aerosol.

Secondary organic aerosol (SOA). SOA arises from both biogenic and anthropogenic sources, and continuously evolves in the atmosphere as a function of multi-generational oxidation and dynamic gas-particle partitioning. Biogenic VOC oxidation can lead to the formation of SOA through a suite of multi-phase reactions, as reviewed recently. ${ }^{132,133}$ SOA likely contributes a substantial fraction of total organic aerosol ${ }^{134}$ but the impact of SOA on the radiative balance of the atmosphere is poorly understood (e.g., ref. 135). Some global models neglect SOA formation from anthropogenic precursor emissions, ${ }^{78}$ which would lead to an underestimate of RF from SOA.

Furthermore, formation of biogenic SOA can be enhanced in the presence of anthropogenic organics and particulate matter, where the anthropogenic species provides greater surface area for condensation and enables additional chemical interactions. ${ }^{136-139}$ As recently reviewed, ${ }^{140}$ the formation mechanisms of SOA can be affected by interactions with anthropogenic pollution in multiple ways, including (1) the partitioning processes to transfer gas-phase biogenic VOC to the particulate phase, (2) the role of $\mathrm{NO}_{x}$ through nitrateinitiated reactions or changing yields depending on $\mathrm{NO}_{x}$ conditions (with changes depending on the specific biogenic VOC), and (3) the contribution of biogenic VOC nucleation to the formation of new particles in the atmosphere. Recent studies estimate that approximately $20-50 \%$ of SOA could result from anthropogenic activity. ${ }^{140-145}$ Anthropogenic enhancement of SOA implies an additional aerosol forcing beyond that reported in the IPCC AR4. Both Hoyle et al. ${ }^{137}$ and Myhre et al. ${ }^{75}$ report that increases in the SOA burden from pre-industrial to present day have resulted in a direct RF of nearly $-0.1 \mathrm{~W} \mathrm{~m}^{-2}$. Spracklen et al. ${ }^{88}$ estimate that if a substantial fraction of global SOA burden is from anthropogenic activity, the aerosol direct forcing is larger $(-0.26 \pm$ $0.15 \mathrm{~W} \mathrm{~m}^{-2}$ ), and they further estimate a cloud albedo effect of $-0.6 \mathrm{~W} \mathrm{~m}^{-2}$. O'Donnell et al. ${ }^{47}$ use simulations with and without SOA for year 2000 meteorological conditions to estimate an overall climate impact of $-0.09 \mathrm{~W} \mathrm{~m}^{-2}$, which includes opposing influences from the direct effect $\left(-0.31 \mathrm{~W} \mathrm{~m}^{-2}\right)$ and indirect effect $\left(+0.23 \mathrm{~W} \mathrm{~m}^{-2}\right)$. In their simulations, particle growth from SOA condensation combined with a larger coagulation sink for small particles leads to a warming indirect effect from SOA. Further work is needed to reconcile the sign of the SOA influence on the cloud albedo feedback.

\subsection{Anthropogenic emission sectors}

In contrast to long-lived greenhouse gases, the climate impact of NTCFs can depend on emission location and chemical interactions with co-emitted species, which can vary strongly by emission sector. Determining the net climate impact of the suite of emissions from an anthropogenic activity requires explicit three-dimensional model calculations that consider interactions and nonlinearities between the co-emitted chemical species, which may have offsetting or additive climate impacts. Global chemistry-climate models are often employed to determine the sectoral RF impacts of the NTCFs but few studies extend to estimate the more computationally expensive climate response (e.g., ref. 5 and 98).

The transportation sub-sectors have received the greatest attention. ${ }^{40,146-156}$ The net climate impacts of biomass burning, ${ }^{157,158}$ electric power production, ${ }^{159,160}$ household fuel burning, ${ }^{161}$ and regional sector impacts ${ }^{156,161-164}$ have also been assessed. Newer studies consider climate impacts across both long-lived greenhouse gases and NTCF gas and aerosol components including aerosol-cloud interactions. ${ }^{148,165}$ In terms of net RF, which has been estimated for several sectors across different modeling systems and emission inventories, road transportation is consistently the largest contributor to warming on short to long timescales, aviation generally produces a small net warming, while shipping emissions yield net cooling on century timescales. ${ }^{166}$ Overall climate impacts may change in the future as various technology controls are applied to different sectors. Black carbon emissions from shipping have been comprehensively reviewed ${ }^{167}$ and are of particular concern in the Arctic because of the local climate sensitivity to snow-ice albedo effects following deposition. ${ }^{156}$

In one study, full implementation of state-of-the art aerosol control technologies in conjunction with increasing greenhouse gases led to an increase in global mean temperature by $2.2 \mathrm{~K}$ in 2030 relative to today, nearly doubling the effect of greenhouse gases alone over this period. ${ }^{98}$ Maximum abatement in the industry and power sectors (dominated by sulfate aerosol) yielded a somewhat lower response of $1.9 \mathrm{~K}$; maximum abatement in the domestic and transport sectors (dominated by black carbon) still caused an increase of $1.4 \mathrm{~K} .{ }^{98}$

A limitation of the sector-based approach to date is that it refers to a fixed mix of emissions. The most desirable approach is to quantify the climate impact of specific policy-relevant energy shifts or emission control policies. Progress has been made in this direction, for example investigating the trade off 
of emissions in electrification of transport, ${ }^{159}$ the impacts of tighter vehicle emission standards, ${ }^{168}$ ethanol versus gasoline fuel use in U.S. fleet, ${ }^{169}$ the implications of global and regional sulfur limits and the use of biofuels in shipping, ${ }^{170,171}$ and hydrogen vehicle fuel. ${ }^{172,173}$ Reducing particulate emissions from residential cooking across the developing world would have strong health benefits, however the co-benefits ${ }^{174}$ or tradeoffs with climate need further investigation.

\subsection{Terrestrial biogeochemical - air pollution feedbacks}

Climate impact assessments have largely neglected feedbacks between air pollutants and biogeochemical cycles. ${ }^{74} \mathrm{O}_{3}$ deposition on vegetation suppresses $\mathrm{CO}_{2}$ uptake by the land or vegetation sink. ${ }^{175}$ One study suggests the magnitudes of the $\mathrm{O}_{3}$ direct $\mathrm{RF}$ and the $\mathrm{O}_{3}$ indirect $\mathrm{RF}$ through $\mathrm{CO}_{2}$ are comparable. ${ }^{33}$ Aerosols reduce the total amount of radiation reaching the surface but can enhance the diffuse component, which may penetrate deeper into a vegetation canopy depending on the ecosystem type and the magnitude of aerosol loading. ${ }^{176-178}$ It is feasible that anthropogenic aerosol may have further substantial effects on the $\mathrm{CO}_{2}$ land sink, by altering the surface energy budget ${ }^{179-181}$ and the amount of precipitation, thereby influencing water stress in vegetation. ${ }^{182}$ Atmospheric deposition of sulfate, nitrate and carbonaceous aerosol to surface ecosystems may impact the carbon cycle but these feedbacks are highly uncertain.

Because terrestrial biogenic emissions are climatically driven, multiple feedbacks can occur between climate, the emissions, and therefore air quality. For example, biogenic VOC emissions are dependent on radiation, temperature and soil moisture. ${ }^{48}$ Atmosphere-biosphere feedbacks through biogenic aerosols have been proposed in the literature, ${ }^{183-185}$ but these are largely estimated by models as it is difficult to quantify these feedbacks with observational studies. A qualitative summary of several of these feedbacks is included in Table 1 where we provide an assessment of the level of confidence in the sign of the response to rising temperatures, along with the impacts of these climate-driven pathways on surface $\mathrm{O}_{3}$ and PM. Finally, land-use changes have also been shown to influence regional air quality by altering emissions from the biosphere. ${ }^{186-189}$

\section{Air quality response to a warming climate}

There are several pathways by which climate change may influence $\mathrm{O}_{3}$ and $\mathrm{PM}$ air quality. Observational evidence and model studies of these processes have been reviewed recently $^{7,13}$ and are summarized in Table 1 . Briefly, the formation and accumulation of air pollutants is known to correlate strongly with local meteorological variables (e.g., temperature, precipitation, relative humidity, and wind). In many cases, the underlying driver of these strong relationships is variability in synoptic conditions (e.g., ref. 190 and 191). For example, over the eastern United States and Europe, observations demonstrate that extreme air pollution $\left(\mathrm{O}_{3}\right.$ and $\left.\mathrm{PM}_{2.5}\right)$ is typically associated with air stagnation events. ${ }^{190,192-198}$ As described below, both modeling and observational analyses suggest an exacerbation of air pollution in a warmer climate, including extreme episodes, at least in some populated regions.
We note that some regions may be particularly sensitive to large feedbacks from natural $\mathrm{O}_{3}$ and aerosol sources, such as wildfires, dust, and biogenic precursors and from changes in chemical and depositional sinks. ${ }^{199-205}$ For example, Southern Europe may be particularly sensitive to climate change due to vegetative feedbacks including increased biogenic VOC emissions and decreased dry deposition when heat leads to closure of plant stomata. ${ }^{206}$

To understand the processes by which $\mathrm{O}_{3}$ and $\mathrm{PM}$ in surface air are influenced by changes in climate, several approaches are used (as reviewed by Jacob and Winner ${ }^{7}$ ):

(1) Sensitivity studies in which individual meteorological parameters are perturbed (e.g., ref. 207 and 208);

(2) Statistical downscaling of future changes in meteorological fields, using correlations between observed changes in air quality indices and meteorological variables from climate models (e.g., ref. 209-211); and

(3) The direct calculation of air quality by various global and regional modeling approaches that include:

(i) Fully coupled global chemistry-climate models (CCMs; Table S1, ESI $\ddagger$ ).

(ii) Fully coupled regional CCMs; ${ }^{215-217}$

(iii) Global-to-urban CCMs (e.g., ref. 218);

(iv) Off-line global or regional chemical transport models (CTMs) forced using projections of meteorological fields from separate atmosphere-ocean general circulation models (AOGCMs) (e.g., ref. 8) or dynamically downscaled meteorology (e.g., ref. 219 and 220).

Approaches (1) and (2) provide valuable process-level relationships that can be used to evaluate the present-climate simulations in the modeling systems under Approach (3). Caution is needed when applying air pollution relationships with meteorological variables on small spatial scales to project air quality responses to future climate change since the sensitivities of air pollution to individual meteorological variables vary in space and time and are non-linear. ${ }^{6,194,205,221-226}$ Statistical downscaling based on synoptic conditions may provide more accurate projections, ${ }^{190,191,210,227}$ though models must credibly simulate changes in these synoptic conditions and it is unclear if current statistical relationships are applicable to future climate conditions.

\subsection{Ozone}

In the case of surface $\mathrm{O}_{3}$, it is well established that in many polluted regions, high- $\mathrm{O}_{3}$ events correlate strongly with temperature due to associations of temperature with stagnation episodes, with enhanced photochemistry, and with biogenic and wildfire emissions. $^{5-8,186,195,200,221,223,228-232}$ Table 1 summarizes current understanding of potential impacts of a warming climate on surface $\mathrm{O}_{3}$ and distinguishes between baseline surface $\mathrm{O}_{3}$ levels (defined as those not influenced directly by local emissions ${ }^{233}$ ) and local-to-regional (LR) responses. Baseline surface $\mathrm{O}_{3}$ is very likely to decrease in a warmer climate because higher water vapor abundances will enhance $\mathrm{O}_{3}$ destruction in low- $\mathrm{NO}_{x}$ regions of the atmosphere and lead to shorter $\mathrm{O}_{3}$ lifetimes. ${ }^{234}$ The increase in temperature itself has little impact on $\mathrm{O}_{3}$ in these regions. ${ }^{228}$ Climate-driven increases in lightning $\mathrm{NO}_{x}$ and exchange of stratospheric $\mathrm{O}_{3}$ 
into the troposphere $e^{17,235,236}$ could oppose the negative feedback from rising humidity in some regions of the atmosphere, but are unlikely to offset the humidity-driven decrease in global surface $\mathrm{O}_{3} \cdot{ }^{236-238}$ In some regions and seasons, higher biogenic emissions from vegetation and soils and shifts in transport pathways for intercontinental pollutant transport could offset the decrease in baseline $\mathrm{O}_{3}$ associated with higher atmospheric water vapor abundances. ${ }^{8,223,239}$ On large spatial scales, Doherty et al $^{232}$ find little response of intercontinental transport pathways themselves to a warming climate, but note enhanced sensitivity of $\mathrm{O}_{3}$ to emissions within the source region (reflecting isoprene increases and thermally driven decomposition of peroxy acetyl nitrate which could otherwise export $\mathrm{NO}_{x}$ downwind) and decreased sensitivity to intercontinental sources (mainly due to higher water vapor).

We synthesize the surface $\mathrm{O}_{3}$ response to climate change as estimated by various modeling systems in Fig. 3 (blue bars and symbols). A major caveat is that many studies use present-day and climate simulations spanning only a few years each due to computational limitations. While these studies highlight the responses of air quality to meteorological changes, the simulations are too short to distinguish a true anthropogenic-forced climate signal from internally generated climate variability (see also Nolte et $a l^{223}$ ). The ranges in Fig. 3 reflect spatial variability as well as differences across models, including in simulation length, scenarios, and reported $\mathrm{O}_{3}$ statistics and thus are not a good measure of the true uncertainty. For example, the multi-model annual, spatial averages with standard deviations that bracket zero ${ }^{240}$ are the net sum of opposing influences from a warming climate: lower baseline $\mathrm{O}_{3}$ levels but higher $\mathrm{O}_{3}$ in polluted regions and seasons. ${ }^{7,234}$ These results are plotted alongside several studies that report spatial ranges for daytime statistics during the high- $\mathrm{O}_{3}$ season. Fig. 3 shows that climate change-induced increases in surface $\mathrm{O}_{3}$ of up to $10 \mathrm{ppb}$ have been estimated for populated regions over the United States by 2050 and up to 6 ppb over Europe by 2030 during the high- $\mathrm{O}_{3}$ season. At the sub-continental scale, models often disagree in terms of the sign and magnitude of changes, such as for summer over the Midwest, Southeast and
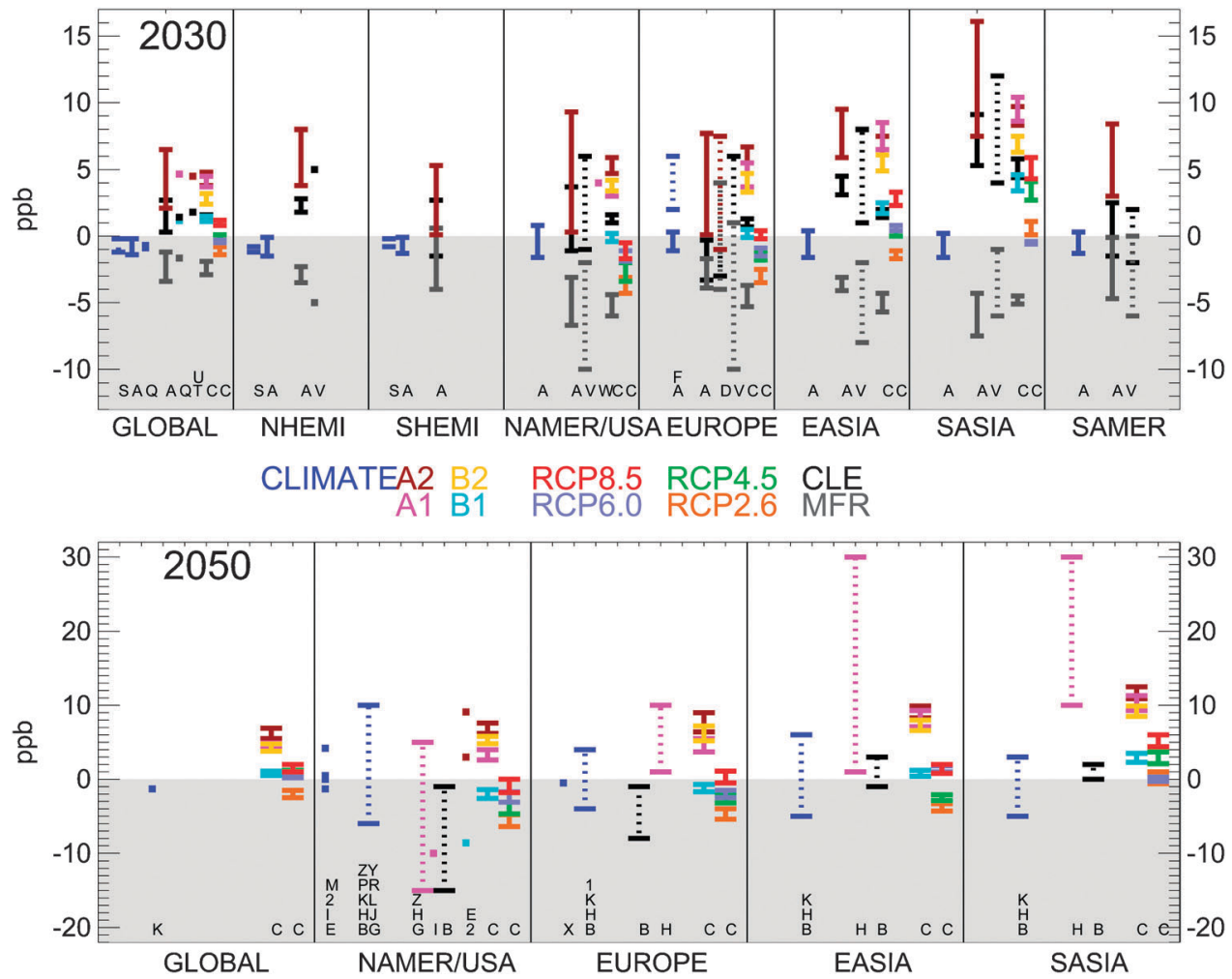

Fig. 3 Changes in surface $\mathrm{O}_{3}(\mathrm{ppb})$ due to climate change alone (dark blue) or emissions changes alone (colored by emission scenario) reported in the literature in 2030 (top) and 2050 (bottom) for selected world regions. Results from individual studies are labeled by letters underneath the corresponding plot symbols. Solid vertical bars represent a combination of ranges as reported in the literature: (1) multi-model mean and standard deviations in annual mean, spatial averages from the ACCENT/Photocomp study for $2030\left(\mathrm{~A}^{240}\right)$; (2) application of a parameterization developed from the multi-model ensemble of the Task Force on Hemispheric Transport of Air Pollution (TF HTAP) regional source-receptor relationships to estimate surface $\mathrm{O}_{3}$ response over the TF HTAP continental regions to emission changes $\left(\mathrm{C}^{66}\right)$; (3) spatial averages across a region, denoted by filled squares $\left(\mathrm{E},{ }^{186} \mathrm{I},{ }^{244} \mathrm{~K},{ }^{242} \mathrm{M},{ }^{220} \mathrm{Q},{ }^{267} \mathrm{~T},{ }^{58} \mathrm{U},{ }^{68} \mathrm{~W},{ }^{28} \mathrm{X},{ }^{287} 2^{286}\right)$; (4) spatial ranges across a region as estimated with one model or combined across several individual modeling studies, denoted by dotted lines $\left(\mathrm{B},{ }^{278} \mathrm{D},{ }^{283} \mathrm{~F}^{224} \mathrm{G},{ }^{8} \mathrm{H},{ }^{239} \mathrm{~J},{ }^{223} \mathrm{~K},{ }^{242} \mathrm{~L},{ }^{245} \mathrm{P},{ }^{286} \mathrm{R},{ }^{363} \mathrm{~S}\right.$; ${ }^{246} \mathrm{~V},{ }^{29} \mathrm{Y},{ }^{298}$ $\left.\mathrm{Z},{ }^{300} 1^{281}\right)$. Regional definitions, methods, and reported metrics (e.g., $24 \mathrm{~h}$ versus daily maximum values over a 1 hour or 8 hour averaging period, annual or seasonal averages) vary across studies, but the $\mathrm{O}_{3}$ changes shown here are self-consistent. Climate change scenarios vary across studies, but are combined into ranges denoted by blue bars because there is little detectable cross-scenario difference in the climate response, particularly in 2030, and many of these estimates are based on simulations that are too short to differentiate cleanly the climate change signal. Tables S2-S5 in the ESI $\ddagger$ contain details on the plotted values. 
Western United States in 2050, though in some regions, such as the Northeastern United States in summer, they consistently show $\mathrm{O}_{3}$ increases. ${ }^{6,7}$

\subsection{Particulate matter}

Particulate matter is also influenced by many of the same processes as $\mathrm{O}_{3}$ (Table 1), but additional complications include opposing influences on the various PM components. ${ }^{7,194,241}$ Climate-driven changes in PM can be large, but they are highly uncertain and model-dependent (Table 1). ${ }^{7}$ Aerosol burdens are particularly sensitive to precipitation changes and are expected to decrease in regions with increased precipitation. ${ }^{186,241-246}$ Regional and seasonal changes in precipitation must be considered since global soluble aerosol burdens do not typically scale with global precipitation changes. ${ }^{98,247}$ Changes in mixing depths and ventilation of the continental boundary layer also contribute to the sign of the aerosol changes but are highly uncertain., 7,219,222,248

Large feedbacks are possible from "natural" aerosol sources (Table 1), particularly carbonaceous aerosols from wildfires, mineral dust, and biogenic precursors to secondary organic aerosol. ${ }^{202-204,229,249-253}$ In regions experiencing warming and drying, wildfires are expected to increase under climate change. ${ }^{254}$ Dust events are known to affect urban areas seasonally, increasing hazardous levels of $\mathrm{PM}_{2.5}$ and reducing visibility in regions downwind of major desert source regions, and in some cases, leading to long-range transport across oceans. ${ }^{255-258}$ As with other types of particulate matter, dust can provide a surface for heterogeneous reactions, leading to enhancement ${ }^{259}$ and uptake of pollutants which can alter the optical properties and solubility of the primary emission. ${ }^{260,261}$ Although dust is mostly considered as "natural", the fraction of "anthropogenic" dust (such as from disturbed soils or construction) is subject to debate with possible values ranging from $5-7 \%{ }^{250}$ to $60 \%,{ }^{249}$ with the latest estimate around $25 \%{ }^{262}$ Primary biogenic aerosols are emitted to the atmosphere in the form of pollen, bacteria, spores, or plant fragments, ${ }^{263-265}$ though knowledge is limited as to their contribution to $\mathrm{PM}_{2.5}$ concentrations or how they will change with climate. $^{5}$

Individual aerosol species respond differently to meteorological changes. Rising temperature and water vapor enhance $\mathrm{SO}_{2}$ oxidation relative to surface loss, increasing sulfate aerosol but decreasing nitrate aerosol. ${ }^{241,242,248,266-269}$ One study, however, shows that observed correlations of temperature and water vapor with sulfate, nitrate, and organic carbon largely reflect their co-variation with synoptic transport rather than these direct impacts. ${ }^{190}$ While warmer temperatures should reduce the partitioning of gas phase secondary organics into the aerosol phase, e.g., ref. 202, they may also increase the biogenic contribution to PM. ${ }^{187,243,244,270}$ SOA formation pathways are strongly influenced by climate as shown in multiple regional and global modeling studies. ${ }^{137,202,271}$ Future changes in oxidant levels can influence PM distributions; ${ }^{32}$ Leibensperger et al. ${ }^{272}$ point out that intercontinental influences of $\mathrm{NO}_{x}$ and $\mathrm{CO}$ emissions on PM can exceed those from $\mathrm{SO}_{2}$ emissions, ${ }^{273}$ particularly in regions with high PM pollution.

\subsection{Air pollution episodes}

Air pollution events are generally associated with stagnation events, sometimes coincident with heat waves. ${ }^{196,197,231,274}$ Even under limited global mean warming scenarios, the frequency of heat waves may increase. ${ }^{275-277}$ A warmer climate is projected to decrease rainfall over southern Europe, creating wintertime deficits that lowers soil water content for the following seasons, contributing to extreme summertime heat wave conditions. ${ }^{278} \mathrm{~A}$ few studies have emphasized positive feedbacks from vegetation (higher emissions and lower stomatal deposition) during heat waves. ${ }^{197,278,279}$ Furthermore, the probability of wildfires, a source of pollutant emissions, increases with temperature (Table 1).

Although the record lengths of surface $\mathrm{O}_{3}$ and PM observations are increasing and allow for new analyses on connections between extreme pollution events and meteorological conditions, additional work is needed to determine their relevance to the response to changing climate. For example, over the Northeastern United States, Leibensperger et al. ${ }^{195}$ report a strong inverse relationship between cyclone frequency in summer, and the number of air stagnation events conducive to high- $\mathrm{O}_{3}$ episodes and Tai et al. ${ }^{194}$ find that stagnant days over the United States are associated with a $2.6 \mu \mathrm{g} \mathrm{m}^{-3}$ increase in $\mathrm{PM}_{2.5}$ in the United States. Appelhans et al. ${ }^{191}$ find similar correlations between winter PM events in Christchurch, New Zealand and daily to inter-annual variations in synoptic conditions.

Several modeling studies for the United States and Europe indicate that high- $\mathrm{O}_{3}$ events are likely to increase in frequency and duration with climate change $8,196,202,209,220,221,223,224,230,244,279-286$ but the large variability in the incidence of these events makes projections of their changes highly uncertain ${ }^{195,284}$ and models often disagree at the regional level. 6,7,228,248,287 Analysis of centuries-long simulations with CCMs, such as those recently completed for CMIP5 (e.g., the four models at the bottom of Table S1, ESI $\ddagger$ ), should permit an assessment of whether a climate change signal on pollution episodes can be cleanly isolated from climate variability.

\section{Projections of regional air quality changes over the next century}

The local response of surface $\mathrm{O}_{3}$ and $\mathrm{PM}$ to climate-driven changes depends also on changing spatial patterns of pollutant emissions (e.g., ref. 140, 141, 194, 205, 207, 285 and 288) and thus is tied to the future emissions trajectories for greenhouse gases and short-lived pollutants. We consider here projections for regional air quality driven by changes in climate and anthropogenic emissions, both separately (Fig. 3 and 4) and combined (Fig. 5 and 6). We focus on the multi-model surface $\mathrm{O}_{3}$ and PM estimates based on the RCP scenarios: ${ }^{16-22}$ the transient climate simulations with interactive chemistry conducted by several CCMs in support of the Fifth phase of the Coupled Model Intercomparison Project (CMIP5; ${ }^{289}$ lines and shading in Fig. 5 and 6); and the decadal "time slice" simulations in CCMs and CTMs conducted in support of the Atmospheric Chemistry and Climate Model Intercomparison Project (ACCMIP; circles and black vertical bars in Fig. 5 and 6). 


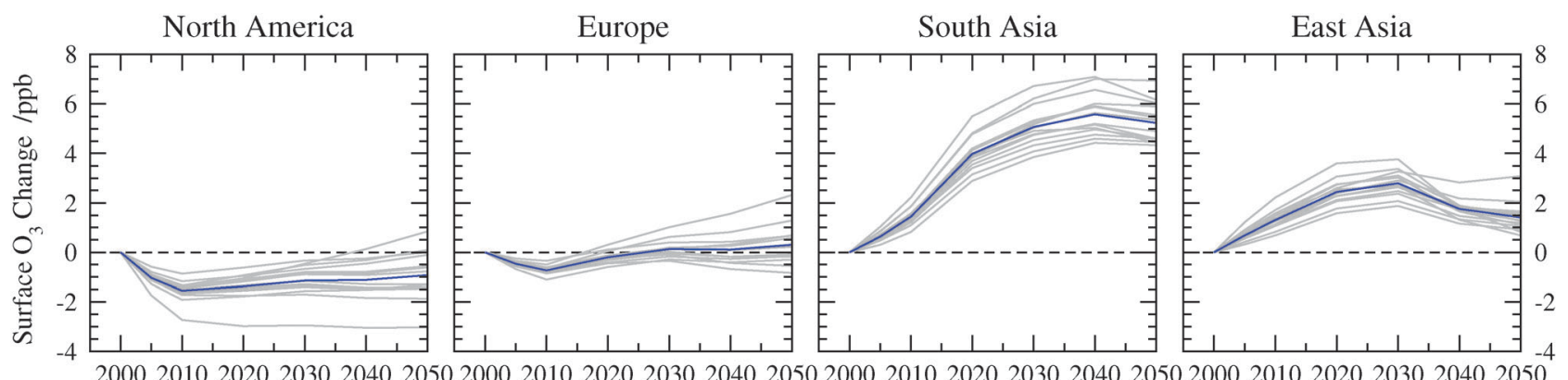
200020102020203020402050200020102020203020402050200020102020203020402050200020102020203020402050
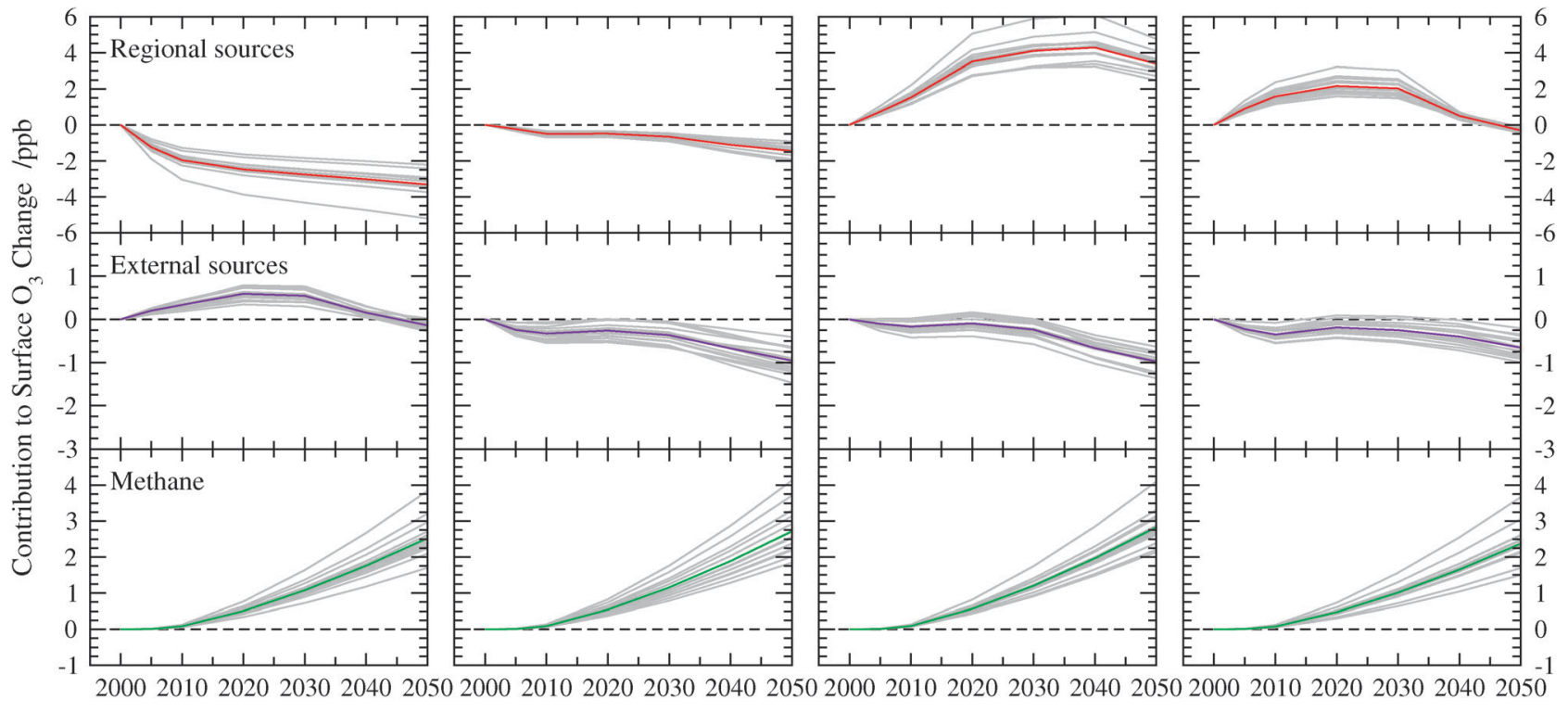

Fig. 4 Individual model (grey lines) and ensemble mean (colored line) spatially averaged $\mathrm{O}_{3}$ projected from the RCP 8.5 emission scenarios for $\mathrm{O}_{3}$ precursors from 2000 to 2050 for the four northern mid-latitude source-regions defined by the Task Force on Hemispheric Transport of Air Pollution (TF HTAP). ${ }^{66,364,365}$ The projections are estimated using model sensitivities diagnosed from emission perturbation simulations relative to a base year of 2001 as described by Wild et al. ${ }^{66}$ using the CTMs that contributed to the TF HTAP source-receptor studies for surface $\mathrm{O}_{3}{ }^{65}$ A source attribution is presented for each region in the lower panels. Reproduced with permission from Fig. 10 of Wild et al. ${ }^{66}$

Ongoing analyses of CMIP5 and ACCMIP simulations will inform the upcoming Intergovernmental Panel on Climate Change Fifth Assessment (IPCC AR5) report. The individual models are described in the references in Table S1 (ESI $\ddagger$ ). In addition, some results are shown for the SRES emissions pathways ${ }^{14,290}$ and for alternative, lower pollution pathways than under the SRES. ${ }^{29}$ Emissions from the biosphere and lightning $\mathrm{NO}_{x}$ generally differ across the models, with some models additionally including climate feedbacks to air pollutant sources and sinks from the biosphere. These CMIP5/ACCMIP results are a first overview; further analysis is in progress.

\subsection{Ozone}

Projected changes in surface $\mathrm{O}_{3}$ for the near-term (2030 and 2050) due to changes solely in climate or solely in emissions of $\mathrm{O}_{3}$ precursors show some general patterns across the globe (Fig. 3). The largest surface $\mathrm{O}_{3}$ changes under the recently developed $\operatorname{RCP}(2.6,4.5,6.0$, and 8.5) emission pathways are much smaller than those projected under the older SRES (A1, A2, B1, B2) scenarios. ${ }^{17,66}$ Alternative, lower pollutant emission scenarios to the SRES scenarios (CLE, MFR) ${ }^{29}$ tend to cover the RCP range. The RCPs assume aggressive control of $\mathrm{NO}_{x}$ and other $\mathrm{O}_{3}$ precursor emission controls globally, ${ }^{23}$ falling below the current legislation $\left(\mathrm{CLE}^{29}\right) 2030$ projections and reaching levels by 2050 that are equivalent to maximum feasible reductions $\left(\mathrm{MFR}^{29}\right)$. Even within this narrow RCP range for global emissions, larger regional shifts in emissions occur. We conclude that the emissiondriven changes across all available scenarios up to 2050 generally span a wider range than the climate-driven changes; ${ }^{240}$ Fig. 3).

The large spatial regions considered here and the coarse resolution of the models may mask oppositely signed changes within smaller regions (e.g., within megacities, whose emissions may increase even under emission control scenarios with nationally declining total emissions ${ }^{291}$ ). Most models do not consider the impact of land-use changes on biogenic emissions and thereby air pollution, but some initial work suggests these impacts could be substantial. For example, Ganzeveld et al. ${ }^{292}$ find that global changes in land-use and land-cover (LULC) under the SRES A2 scenario could lead to $\mathrm{O}_{3}$ changes of $\sim 20 \%$ by 2050 in the tropics, with increases of $6 \mathrm{ppb}$ over the Amazon forest and of $9 \mathrm{ppb}$ over the central African rain forest, and smaller changes (less than 5-10\%) over populated regions at northern mid-latitudes. Over the United States, Chen et al. ${ }^{280}$ suggest LULC can lead to $\pm 5 \mathrm{ppb}$ changes in surface $\mathrm{O}_{3}$ by 2050 in some locations. 


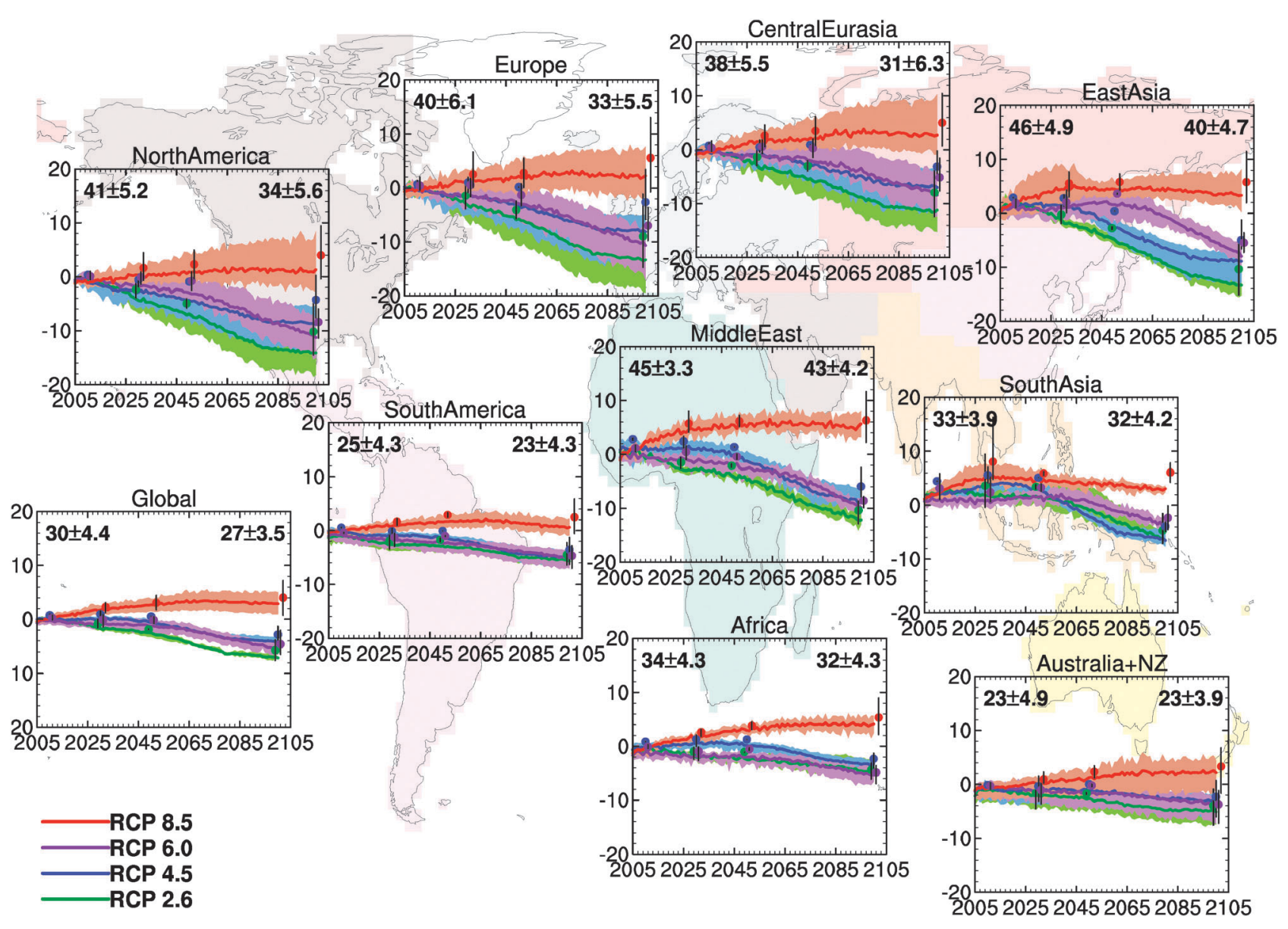

Fig. 5 Changes in annual mean surface ozone (ppb mole fraction) averaged over selected world regions (shaded land regions) following the RCP scenarios. Colored lines denote the 4-model average from transient simulations with CMIP5 chemistry-climate models; shading covers the full range across models (Table S1, ESI $\ddagger$ ). Filled circles with vertical lines represent decadal multi-model averages from the 2010, 2030, 2050, and 2100 ACCMIP time-slice simulations; the number of models varies with time slice and scenario (Table S1, ESI $\ddagger$ ). The circles are colored by RCP scenario and offset by a year to clearly distinguish the vertical black lines which denote the full range of ACCMIP model results. Changes are relative to the 1986-2005 reference period for the transient simulations, and relative to the average of the 1980 and 2000 decadal average time slices for the ACCMIP ensemble. The average value for this reference period, averaged across all models is shown in each panel, with the standard deviation reflecting the model range (transient CMIP5 models on the upper left; ACCMIP models on the upper right). In cases where multiple ensemble members are available from a single model, they are averaged prior to inclusion in the multi-model mean.

Changes in baseline $\mathrm{O}_{3}$ levels must be considered alongside the impacts of regional emission changes in any future projection as these components together determine regional air quality. Rising global emissions (particularly $\mathrm{NO}_{x}$ and $\mathrm{CH}_{4}$ ) can offset $\mathrm{O}_{3}$ decreases obtained with regional emission controls, e.g., ref. 28 and 66 For example, under the RCP8.5 scenario, the $\mathrm{O}_{3}$ decreases over North America are at least partially offset by rising external sources until 2040, and rising global $\mathrm{CH}_{4}$ raises baseline $\mathrm{O}_{3}$ levels over the entire northern hemisphere (Fig. 4). ${ }^{66}$ The contribution from $\mathrm{CH}_{4}$ to baseline surface $\mathrm{O}_{3}$ is fairly uniform globally, although the annual mean $\mathrm{O}_{3}$ sensitivity to $\mathrm{CH}_{4}$ ranges by a factor of two across individual models. ${ }^{38,58,65,66}$ This uncertainty leads to discrepancies in the magnitude and, in the case of Europe under the RCP8.5 scenario, the sign of the overall surface $\mathrm{O}_{3}$ change (Fig. 4). Future increases in shipping emissions, which are subjected to less stringent regulations than land-based emission sectors, may also contribute to raising baseline pollution levels in some regions. ${ }^{293,294}$ Both rising baseline $\mathrm{O}_{3}$ levels and a warming climate could contribute to lengthening the $\mathrm{O}_{3}$ pollution season. ${ }^{28,223,282}$

Fig. 5 shows projected annual mean surface $\mathrm{O}_{3}$ changes over the 21 st century for selected world regions with the current generation of chemistry-climate models using the RCP trajectories. Large inter-annual variations are evident, reflecting model-generated climate variability, with larger variability over smaller regions, as well as within specific seasons, and in the frequency of high- $\mathrm{O}_{3}$ events (not shown). The models span a fairly wide range of $\mathrm{O}_{3}$ responses, consistent with prior studies, ${ }^{57,65,240}$ so we focus here on the robust features. Under all of the RCP scenarios, global $\mathrm{NO}_{x}$ emissions decline over the next century (Fig. 1), decreasing surface $\mathrm{O}_{3}$ in all regions by 2100 with the notable exception of RCP8.5. Comparison of Fig. 5 (which includes changes driven by both emissions and climate) with previous published RCP emission-only projections to 2050 (see Fig. 8 of Wild et al. ${ }^{66}$ and Fig. 4 for RCP8.5) suggests that over many regions, the range in surface $\mathrm{O}_{3}$ projections is dominated by emission changes. This comparison 


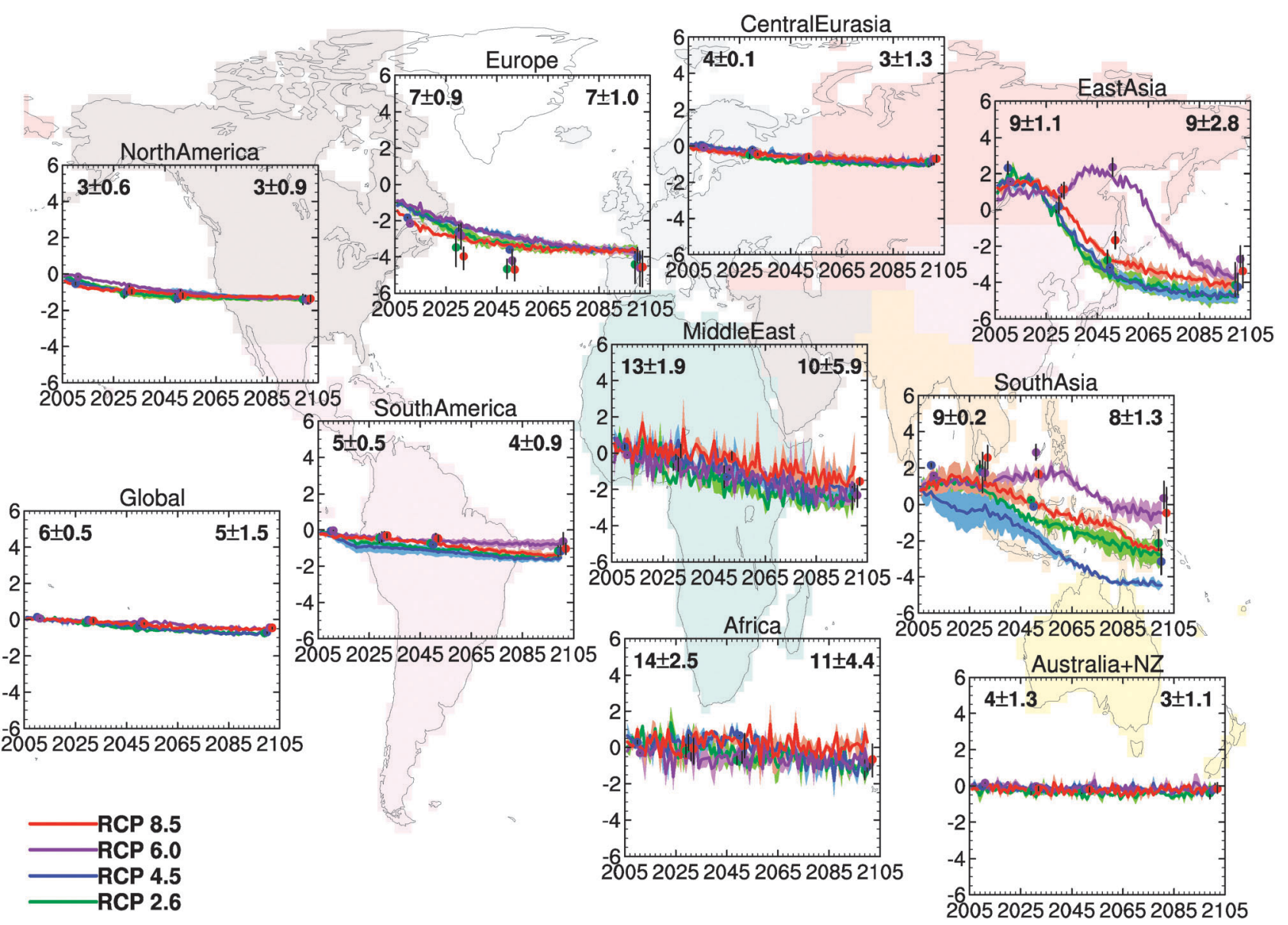

Fig. 6 Changes in annual mean surface $\mathrm{PM}_{2.5}$ (ng per g-air) averaged over selected world regions (shaded land regions) following the RCP scenarios. See Fig. 5 caption for details. PM2.5 estimates are from the italicized models in Table S1 (ESI $\ddagger$ ), calculated as the sum of individual aerosol components (black carbon + organic carbon, + sulfate + secondary organic aerosol $+0.1 *$ dust $+0.25^{*}$ sea salt). Nitrate was not reported for most models and thus is not included here.

is limited, however, by different regional definitions (Fig. 4 includes oceanic boxes whereas Fig. 5 includes spatial averages over land only) and the use of different models (CTMs in Fig. 4 vs. mostly CCMs in Fig. 5). Under RCP8.5, the rise in $\mathrm{CH}_{4}$ (Fig. 1) increases surface $\mathrm{O}_{3}$ levels (Fig. 4). The strong warming in RCP8.5 may induce additional discrepancies between Fig. 4 and 5 by altering both regional $\mathrm{O}_{3}$ production and baseline levels, e.g. ref. 8, 221, 232 and 239.

\subsection{Particulate matter}

Compared to $\mathrm{O}_{3}$, we find fewer 21 st century projections of PM distributions over the next century. Those that exist are difficult to compare due to variations in study region and reported $\mathrm{PM}$ metrics, with some studies reporting only specific PM components (sulfate, nitrate, black carbon, organic) and sizes. $^{31,186,241,242,244-246,267,295-301}$ Future PM, like $\mathrm{O}_{3}$, is expected to be driven by changes in both emissions and climate.

PM changes driven by local-to-regional anthropogenic emissions are complex, depend on regional oxidant levels (e.g., ref. 32 and 248), and cannot simply be scaled to changes in regional emissions. Nevertheless, changes in sulfate aerosol concentrations generally follow changes in $\mathrm{SO}_{2}$ emissions. Changes in $\mathrm{NO}_{x}$ emissions influence nitrate aerosols to a lesser extent than the $\mathrm{SO}_{2}$-sulfate relationship due to competition between sulfate and nitrate for ammonium, such that nitrate aerosol is inversely dependent on sulfate. Increases in ammonia $\left(\mathrm{NH}_{3}\right)$ emissions in conjunction with $\mathrm{SO}_{2}$ reductions enhance nitrate aerosol, offsetting some of benefit from $\mathrm{SO}_{2}$ controls. ${ }^{241}$ Continued reductions in $\mathrm{SO}_{2}$ emissions alongside rising $\mathrm{NH}_{3}$ emission could lead to nitrate aerosol levels equivalent to or larger than sulfate aerosol levels in some regions over the 21 st century. ${ }^{295,301}$ Projected changes in U.S. aerosol for 2050 are dominated by anthropogenic emission changes except in regions where large precipitation changes are projected ${ }^{186,241,243,245}$ or those that are heavily impacted by wildfires. ${ }^{204}$ Future growth in anthropogenic aromatic emissions could lead to a larger anthropogenic contribution to secondary organic aerosol. ${ }^{187}$ Carmichael et al. ${ }^{299}$ project that changes in $\mathrm{BC}$ and $\mathrm{SO}_{2}$ emissions from Asia over the period 2000 to 2030 will result in increased $\mathrm{PM}_{2.5}$ concentrations over the region.

Regional $\mathrm{PM}_{2.5}$ projections over the 21 st century obtained with the CMIP5 and ACCMIP CCMs and CTMs are shown in Fig. 6. Over most of the globe, and in some industrial regions (North America, Europe, and Central Eurasia), an overall decline in $\mathrm{PM}_{2.5}$ is projected, with little difference across the four scenarios. The particularly noisy projections over Africa, the Middle East, and to some extent Australia, 

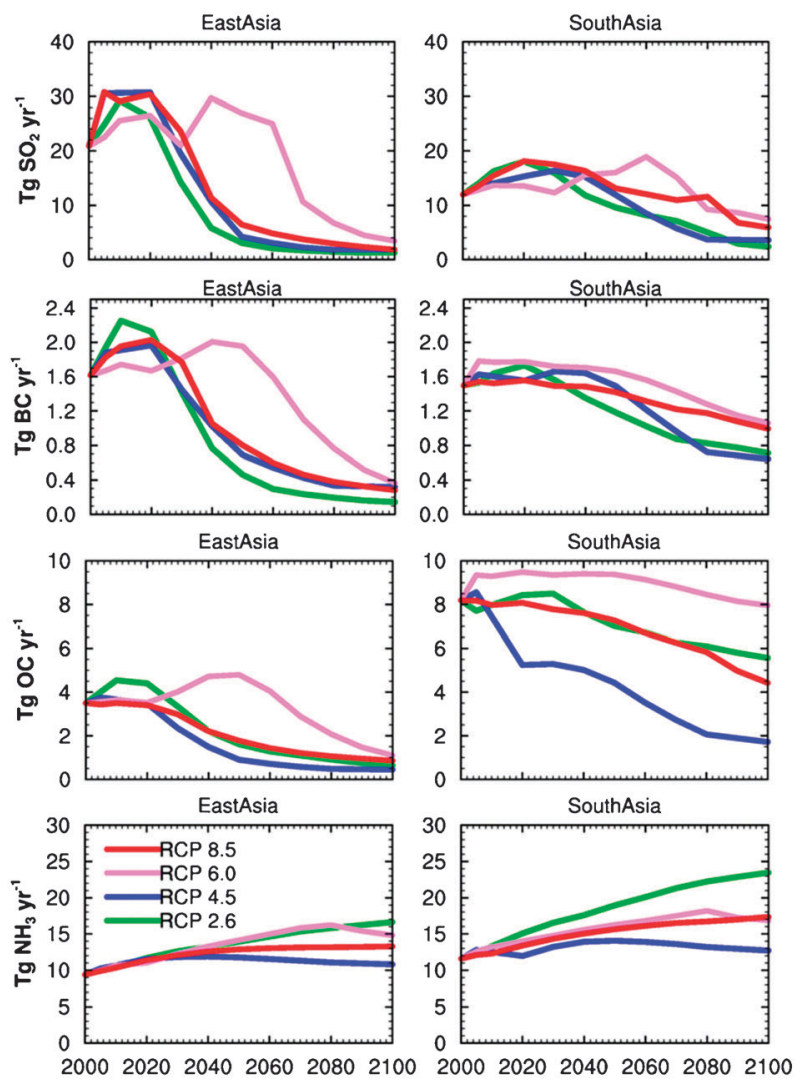

Fig. 7 RCP emissions (2000-2100) of aerosols and precursor emissions from anthropogenic plus biomass burning sources, averaged over two of the regions in Fig. 6 and 7 (East Asia, left column; South Asia, right column).

reflect the dominance of dust sources in these regions and the strong dependence on inter-annual meteorological variability. Over South and East Asia, the $\mathrm{PM}_{2.5}$ projections do not rank according to the RCP RFs. Instead, RCP6.0 represents the high end of the $\mathrm{PM}_{2.5}$ range and $\mathrm{RCP} 4.5$ represents the low end. Over South Asia, the $\mathrm{PM}_{2.5}$ projections are strongly tied to the $\mathrm{OC}$ emissions (Fig. 7). South Asian $\mathrm{SO}_{2}$ emissions decline similarly under all of the RCPs, with the exception of RCP6.0 in which $\mathrm{SO}_{2}$ emissions may contribute to raising $\mathrm{PM}_{2.5}$ relative to the other RCP scenarios from 2050 to 2070 (Fig. 7). Over East Asia, the different $\mathrm{PM}_{2.5}$ projections likely reflect a combination of the changes in $\mathrm{SO}_{2}$ and carbonaceous aerosols (Fig. 7).

\section{Bridging knowledge gaps}

Multi-decadal and multi-century simulations with fully coupled chemistry-climate models as summarized in Fig. 5 and 6 offer a new approach to study interactions between climate and air quality. In particular, these models provide new opportunities to isolate an anthropogenic climate signal on air quality relative to that from climate variability, which has not been possible in most published studies to date. Some of the models also include a well-resolved stratosphere, enabling assessment of the impact of stratospheric changes, including ozone depletion and recovery, on tropospheric ozone and the tropospheric oxidizing capacity. Inclusion of prognostic aerosol-cloud interactions in these models further allows for new insights into the processes contributing to regional climate responses to aerosol forcings. Ongoing community efforts to evaluate rigorously the current generation of chemistry-climate and chemical transport models with process-level observational and laboratory constraints should help bridge knowledge gaps. We focus below on a few areas where current research efforts are expected to advance knowledge rapidly.

\section{Informing air pollution and climate change mitigation}

One of the more robust conclusions from work over the past decade is that $\mathrm{CH}_{4}$ controls are a viable strategy for joint mitigation of climate warming and global $\mathrm{O}_{3}$ pollution (e.g., ref. 30, Section 2.1). Abating $\mathrm{CH}_{4}$ should help to offset some of warming expected from continued removal of atmospheric aerosol (sulfate) motivated by improving public health. The quantitative impact of $\mathrm{CH}_{4}$ oxidation on baseline surface $\mathrm{O}_{3}$ is uncertain, with the full model range spanning a factor of two. ${ }^{66}$ Narrowing this range likely requires better constraints on global $\mathrm{NO}_{x}$ distributions; ${ }^{38,58}$ new space-based approaches may be particularly useful. ${ }^{302-308}$

Black carbon mitigation is another approach under consideration to improve air quality and lessen global warming, with several emission control strategies identified ${ }^{30}$ but substantial uncertainty remains regarding the varied roles by which black carbon affects climate (Section 2.2). Recent advances have been made in characterizing and propagating uncertainties through the multitude of processes governing the emission of radiatively active species and their atmospheric distributions and climate impacts. ${ }^{38,309,310}$ Additional work is needed to extend these uncertainty analyses to other chemical species and anthropogenic sectors. By identifying which processes contribute most to uncertainties, these approaches inform the science community as to where future investments may be most salient.

\section{Evaluating chemistry-climate models}

A wide range of model estimates exists for regional air quality both at present and in the future, even along a given emission trajectory (Fig. 3-6). Growing record lengths of historically observed relationships between relevant meteorological variables and air quality provide useful information for evaluating models (e.g. ref. 194, 205, 226, 311-314) and may also help to improve our understanding of the links between air quality and climate though further study is required. Space-based constraints on instantaneous radiative forcing from $\mathrm{O}_{3}$ and aerosols could aid in characterizing model bias in RF estimates. $^{76,83,315,316}$ These observational approaches, combined with multi-model analysis that seeks to link differences across models to specific processes ${ }^{317-319}$ would help to reduce uncertainties in both present-day and projected air pollution estimates.

\section{Constraining chemical mechanisms}

Fundamental questions remain in our mechanistic understanding that severely limit confidence in projecting future air quality in a changing climate. For example, meta-analysis indicates that 
the sensitivity of $\mathrm{O}_{3}$ to climate change is strongly dependent on the treatment of organic nitrates $\left(\mathrm{RONO}_{2}\right)$, specifically those from isoprene. ${ }^{6,7,320}$ The rate at which $\mathrm{RONO}_{2}$ reacts to recycle $\mathrm{NO}_{x}$ is poorly understood ${ }^{321,322}$ and ranges from $0-100 \%$ are used in CCMs and CTMs; this range affects the sign of the $\mathrm{O}_{3}$ response to changes in BVOC emissions. ${ }^{323-326}$ Chemical mechanisms that include $\mathrm{RONO}_{2}$ formation without recycling $\mathrm{NO}_{x}$ via subsequent reaction display little biogenic VOC-ozone-climate sensitivity, ${ }^{8}$ and mechanisms that ignore $\mathrm{RONO}_{2}$ altogether show large biogenic VOC-ozone-climate sensitivity. ${ }^{242}$ There is additional uncertainty in the $\mathrm{RONO}_{2}$ yield from isoprene oxidation with laboratory yields ranging from $4-12 \%$ (e.g., see summary in Horowitz et al., ${ }^{324}$ and newer findings ${ }^{327,328}$ ). Knowledge of BVOC oxidation and subsequent SOA formation is advancing rapidly but uncertainties remain. ${ }^{54,132,140,329}$ Aerosol-oxidant interactions also require further study as they may determine PM air quality in some regions. $^{32,272}$

Oceanic reactive halogen species released into the atmosphere by the photodecomposition of organohalogens (including iodine-containing species) and via autocatalytic recycling on sea-salt aerosols contribute to $\mathrm{O}_{3}$ destruction and may play an important role in both pre-industrial and present-day $\mathrm{O}_{3}$ budgets and tropospheric oxidizing capacity. ${ }^{330-335}$ Tropospheric halogen chemistry is not included in the model projections reviewed here (Fig. 3-6).

\section{Reducing uncertainty in aerosol forcing}

A new generation of global models allows deeper study at the process level as they include aerosol microphysics and prognostic aerosol cloud interactions. However, large variability between models ${ }^{87,130}$ highlights the need for detailed evaluation of aerosol microphysical schemes before uncertainty in aerosol forcing can be reduced. Synthesis of field observations to develop datasets with global coverage to evaluate models will be important. New approaches are also required to understand the microphysical processes that are most responsible for model diversity helping to prioritize future research directions. ${ }^{336}$

\section{Identifying robust regional air pollution and climate responses}

The northern mid-latitudes have garnered the most attention in the literature in terms of air quality and climate interactions; more work is needed to understand the future evolution of air quality in the tropics and southern hemisphere. More reliable projections of air quality require confidence in the regional climate responses, including precipitation, the positioning of mid-latitude storm tracks and subtropical high pressure systems as well as convection (e.g., ref. 6, 7 and 337). Improved understanding of the spatially resolved global climate response as compared with the regional climate response to locally changing $\mathrm{O}_{3}$ and aerosols from specific emission control strategies (including effects on the hydrologic cycle, temperature and circulation) is needed, particularly for the NTCFs in order to bypass current limitations in the global RF metric. However, identifying a statistically significant signal detectable over internal climate model variability for relatively small net climate impacts from regional or sectoral emissions represents a non-trivial challenge and may even be impossible. ${ }^{338}$
The published literature debates whether the spatial pattern of the future surface temperature response to aerosol forcing mirrors that from greenhouse-gas forcing or rather follows the local aerosol forcing patterns. ${ }^{108,111,112,339-341}$ A multimodel analysis begins to reconcile these previous findings, indicating a strong sensitivity of the surface temperature response to the latitudinal forcing distribution but limited sensitivity to longitude. ${ }^{342}$ Regional precipitation may be particularly sensitive (both sign and magnitude) to aerosol forcing location. $^{131}$

Advancing knowledge of anthroposphere-biosphere interactions

Human interactions with the terrestrial biosphere are a major uncertainty but crucial to understand because vegetation acts as both a source and a sink for many air pollutants (e.g., ref. 13 and 199). The attribution of $\mathrm{O}_{3}$ and $\mathrm{PM}$ air pollution between "anthropogenic" and "biogenic" sources is complicated by chemistry that involves both anthropogenic and biogenic precursors for both $\mathrm{O}_{3}$ and aerosol, ${ }^{141,343}$ and by land-use changes which alter biogenic sources (e.g., ref. 344 and 345). A major uncertainty regarding BVOC feedbacks is the opposing influences of rising $\mathrm{CO}_{2}$ versus rising temperature. ${ }^{346}$ Sources from agriculture and livestock sectors are generally poorly constrained but non-negligible, particularly for $\mathrm{CH}_{4}{ }^{347}$ and $\mathrm{NH}_{3}{ }^{348}$ Human-driven changes in land-use and land cover, such as urbanization or shifts between forests and agriculture, could dramatically alter future $\mathrm{O}_{3}$ and aerosol precursor emissions from the biosphere ${ }^{187,189,279}$ as well as dry deposition, ${ }^{188}$ and should be considered in future assessments.

\section{Acknowledgements}

We thank K.-D. Gottschaldt and F. Dentener for useful comments on earlier versions and $\mathrm{O}$. Wild for providing text files of the TF HTAP model projections for 2030 and 2050. Funding is acknowledged from: the NASA Air Quality Applied Science Team (AQAST) (NNX12AF15G) to AMF; the UK National Environment Research Council (NERC) (NE/G015015/1) to DVS; the Joint DECC and Defra Integrated Climate Programme (GA01101) to WJC, GAF, FMO and SR; the Natural Environment Research Council to IAM; the DLR Earth System Model Validation (ESMVal) Project (VE, MR); New Zealand Ministry of Science and Innovation for funding and NIWA HPC facility (GZ). The CESM project is supported by the National Science Foundation and the Office of Science (BER) of the US Department of Energy. The National Center for Atmospheric Research is operated by the University Corporation for Atmospheric Research under sponsorship of the National Science Foundation. The work by LLNL was performed under Contract DE-AC52-07NA27344 and used the computing resources of NERSC, which is supported by the Office of Science (BER) of the U.S. Dept. of Energy under Contract DE-AC02-05CH11231.

\section{References}

1 S. C. Anenberg, L. W. Horowitz, D. Q. Tong and J. J. West, Environ. Health Perspect., 2010, 118, 1189-1195, DOI: 10.1289] ehp.0901220.

2 F. Raes and J. H. Seinfeld, Atmos. Environ., 2009, 43, 5132-5133. 
3 D. Shindell, J. C. I. Kuylenstierna, E. Vignati, R. van Dingenen, M. Amann, Z. Klimont, S. C. Anenberg, N. Muller, G. JanssensMaenhout, F. Raes, J. Schwartz, G. Faluvegi, L. Pozzoli, K. Kupiainen, L. Höglund-Isaksson, L. Emberson, D. Streets, V. Ramanathan, K. Hicks, N. T. K. Oanh, G. Milly, M. Williams, V. Demkine and D. Fowler, Science, 2012, 335, 183-189.

4 T. Wigley, L. Clarke, J. Edmonds, H. Jacoby, S. Paltsev, H. Pitcher, J. Reilly, R. Richels, M. Sarofim and S. Smith, Clim. Change, 2009, 97, 85-121.

5 M. Z. Jacobson and D. G. Streets, J. Geophys. Res., [Atmos.], 2009, 114, D08118.

6 C. P. Weaver, E. Cooter, R. Gilliam, A. Gilliland, A. Grambsch, D. Grano, B. Hemming, S. W. Hunt, C. Nolte, D. A. Winner, X.-Z. Liang, J. Zhu, M. Caughey, K. Kunkel, J.-T. Lin, Z. Tao, A. Williams, D. J. Wuebbles, P. J. Adams, J. P. Dawson, P. Amar, S. He, J. Avise, J. Chen, R. C. Cohen, A. H. Goldstein, R. A. Harley, A. L. Steiner, S. Tonse, A. Guenther, J.-F. Lamarque, C. Wiedinmyer, W. I. Gustafson, L. R. Leung, C. Hogrefe, H.-C. Huang, D. J. Jacob, L. J. Mickley, S. Wu, P. L. Kinney, B. Lamb, N. K. Larkin, D. McKenzie, K.-J. Liao, K. Manomaiphiboon, A. G. Russell, E. Tagaris, B. H. Lynn, C. Mass, E. Salathé, S. M. O'neill, S. N. Pandis, P. N. Racherla, C. Rosenzweig and J.-H. Woo, Bull. Am. Meteorol. Soc., 2009, 90, 1843-1863.

7 D. J. Jacob and D. A. Winner, Atmos. Environ., 2009, 43, 51-63.

8 S. L. Wu, L. J. Mickley, E. M. Leibensperger, D. J. Jacob, D. Rind and D. G. Streets, J. Geophys. Res., [Atmos.], 2008, 113, D06302.

9 J. Hansen, M. Sato, R. Ruedy, A. Lacis and V. Oinas, Proc. Natl. Acad. Sci. U. S. A., 2000, 97, 9875-9880.

10 P. Forster, V. Ramaswamy, P. Artaxo, T. Berntsen, R. Betts, D. W. Fahey, J. Haywood, J. Lean, D. C. Lowe, G. Myhre, J. Nganga, R. Prinn, G. Raga, M. Schulz and R. Van Dorland, in Climate Change 2007: The Physical Science Basis. Contribution of Working Group I to the Fourth Assessment Report of the Intergovernmental Panel on Climate Change, ed. D. Qin, M. Manning, Z. Chen, M. Marquis, K. B. Averyt, M. Tignor and H. L. Miller, Cambridge University Press, Cambridge, United Kingdom and New York, NY, USA, 2007.

11 J. Hansen, M. Sato, R. Ruedy, L. Nazarenko, A. Lacis, G. A. Schmidt, G. Russell, I. Aleinov, M. Bauer, S. Bauer, N. Bell, B. Cairns, V. Canuto, M. Chandler, Y. Cheng, A. Del Genio, G. Faluvegi, E. Fleming, A. Friend, T. Hall, C. Jackman, M. Kelley, N. Kiang, D. Koch, J. Lean, J. Lerner, K. Lo, S. Menon, R. Miller, P. Minnis, T. Novakov, V. Oinas, J. Perlwitz, J. Perlwitz, D. Rind, A. Romanou, D. Shindell, P. Stone, S. Sun, N. Tausnev, D. Thresher, B. Wielicki, T. Wong, M. Yao and S. Zhang, J. Geophys. Res., 2005, 110, D18104.

12 T. Andrews, P. M. Forster, O. Boucher, N. Bellouin and A. Jones, Geophys. Res. Lett., 2010, 37, L14701.

13 I. S. A. Isaksen, C. Granier, G. Myhre, T. K. Berntsen, S. B. Dalsøren, M. Gauss, Z. Klimont, R. Benestad, P. Bousquet, W. Collins, T. Cox, V. Eyring, D. Fowler, S. Fuzzi, P. Jöckel, P. Laj, U. Lohmann, M. Maione, P. Monks, A. S. H. Prevot, F. Raes, A. Richter, B. Rognerud, M. Schulz, D. Shindell, D. S. Stevenson, T. Storelvmo, W. C. Wang, M. van Weele, M. Wild and D. Wuebbles, Atmos. Environ., 2009, 43, 5138-5192.

14 N. Nakicenovic and R. Swart, Special Report on Emission Scenarios: A Special Report of Working Group III of the Intergovernmental Panel on Climate Change, Cambridge University Press, Cambridge, U.K., 2000.

15 R. H. Moss, J. A. Edmonds, K. A. Hibbard, M. R. Manning, S. K. Rose, D. P. van Vuuren, T. R. Carter, S. Emori, M. Kainuma, T. Kram, G. A. Meehl, J. F. B. Mitchell, N. Nakicenovic, K. Riahi, S. J. Smith, R. J. Stouffer, A. M. Thomson, J. P. Weyant and T. J. Wilbanks, Nature, 2010, 463, 747-756.

16 D. van Vuuren, J. Edmonds, M. Kainuma, K. Riahi, A. Thomson, K. Hibbard, G. Hurtt, T. Kram, V. Krey, J.-F. Lamarque, T. Masui, M. Meinshausen, N. Nakicenovic, S. Smith and S. Rose, Clim. Change, 2011, 109, 1-27.
17 J.-F. Lamarque, G. Kyle, M. Meinshausen, K. Riahi, S. Smith, D. van Vuuren, A. Conley and F. Vitt, Clim. Change, 2011, 109, $1-22$.

18 M. Meinshausen, S. Smith, K. Calvin, J. Daniel, M. Kainuma, J. F. Lamarque, K. Matsumoto, S. Montzka, S. Raper, K. Riahi, A. Thomson, G. Velders and D. P. van Vuuren, Clim. Change, 2011, 109, 1-29.

19 T. Masui, K. Matsumoto, Y. Hijioka, T. Kinoshita, T. Nozawa, S. Ishiwatari, E. Kato, P. Shukla, Y. Yamagata and M. Kainuma, Clim. Change, 2011, 109, 1-18.

20 K. Riahi, S. Rao, V. Krey, C. Cho, V. Chirkov, G. Fischer, G. Kindermann, N. Nakicenovic and P. Rafaj, Clim. Change, $2011,109,1-25$.

21 A. Thomson, K. Calvin, S. Smith, G. Kyle, A. Volke, P. Patel, S. Delgado-Arias, B. Bond-Lamberty, M. Wise, L. Clarke and J. Edmonds, Clim. Change, 2011, 109, 1-18.

22 D. van Vuuren, E. Stehfest, M. den Elzen, T. Kram, J. van Vliet, S. Deetman, M. Isaac, K. Klein Goldewijk, A. Hof, A. Mendoza Beltran, R. Oostenrijk and B. van Ruijven, Clim. Change, 2011, 109, 1-22.

23 D. P. van Vuuren, L. F. Bouwman, S. J. Smith and F. Dentener, Curr. Opin. Environ. Sustainability, 2011, 3, 359-369.

24 A. Arneth, S. P. Harrison, S. Zaehle, K. Tsigaridis, S. Menon, P. J. Bartlein, J. Feichter, A. Korhola, M. Kulmala, D. O'Donnell, G. Schurgers, S. Sorvari and T. Vesala, Nat. Geosci., 2010, 3, 525-532.

25 D. Ehhalt, M. Prather, F. J. Dentener, R. Derwent, E. Dlugokencky, E. Holland, I. Isaksen, J. Katima, V. Kirchhoff, P. Matson, P. Midgley and M. Wang, in Climate Change 2001: The Physical Science Basis. Contribution of Working Group I to the Third Assessment Report of the Intergovernmental Panel on Climate Change, ed. Y. Ding, D. J. Griggs, M. Noguer, P. J. van der Linden, X. Dai, K. Maskell and C. A. Johnson, Cambridge University Press, Cambridge, United Kingdom and New York, NY, USA, 2001.

26 M. Gauss, G. Myhre, G. Pitari, M. J. Prather, I. S. A. Isaksen, T. K. Berntsen, G. P. Brasseur, F. J. Dentener, R. G. Derwent, D. A. Hauglustaine, L. W. Horowitz, D. J. Jacob, M. Johnson, K. S. Law, L. J. Mickley, J. F. Müller, P. H. Plantevin, J. A. Pyle, H. L. Rogers, D. S. Stevenson, J. K. Sundet, M. van Weele and O. Wild, J. Geophys. Res., 2003, 108, 4292.

27 M. M. Fry, V. Naik, J. J. West, M. D. Schwarzkopf, A. M. Fiore, W. J. Collins, F. J. Dentener, D. T. Shindell, C. Atherton, D. Bergmann, B. N. Duncan, P. Hess, I. A. MacKenzie E. Marmer, M. G. Schultz, S. Szopa, O. Wild and G. Zeng, J. Geophys. Res., 2012, 117, D07306.

28 A. M. Fiore, D. J. Jacob, B. D. Field, D. G. Streets, S. D. Fernandes and C. Jang, Geophys. Res. Lett., 2002, 29, 1919.

29 F. Dentener, D. Stevenson, J. Cofala, R. Mechler, M. Amann, P. Bergamaschi, F. Raes and R. Derwent, Atmos. Chem. Phys., 2005, 5, 1731-1755.

30 UNEP/WMO, Integrated Assessment of Black Carbon and Tropospheric Ozone, Nairobi, Kenya, 2011.

31 S. Menon, et al., Environ. Res. Lett., 2008, 3, 024004.

32 N. Unger, D. T. Shindell, D. M. Koch and D. G. Streets, Proc. Natl. Acad. Sci. U. S. A., 2006, 103, 4377-4380.

33 S. Sitch, P. M. Cox, W. J. Collins and C. Huntingford, Nature, 2007, 448, U791-U794.

34 W. J. Collins, S. Sitch and O. Boucher, J. Geophys. Res., 2010, 115, D23308.

35 Y. Wang and D. J. Jacob, J. Geophys. Res., 1998, 103, $31,123-131,135$.

36 J. S. Fuglestvedt, T. K. Berntsen, I. S. A. Isaksen, H. Mao, X.-Z. Liang and W.-C. Wang, Atmos. Environ., 1999, 33, 961-977.

37 C. E. Johnson and R. G. Derwent, Clim. Change, 1996, 34, 439-462.

38 C. D. Holmes, Q. Tang and M. J. Prather, Proc. Natl. Acad. Sci. U. S. A., 2011, 108, 10997-11002.

39 O. Wild, M. J. Prather and H. Akimoto, Geophys. Res. Lett., 2001, 28, 1719-1722.

40 N. Unger, Geophys. Res. Lett., 2011, 38, L20803.

41 T. K. Berntsen, J. S. Fuglestvedt, M. M. Joshi, K. P. Shine, N. Stuber, M. Ponater, R. Sausen, D. A. Hauglustaine and L. Li, Tellus, Ser. B, 2005, 57, 283-304. 
42 V. Naik, D. Mauzerall, L. Horowitz, M. D. Schwarzkopf, V. Ramaswamy and M. Oppenheimer, J. Geophys. Res., 2005, 110, D24306.

43 R. Derwent, D. Stevenson, R. Doherty, W. Collins, M. Sanderson and C. Johnson, Clim. Change, 2008, 88, 385-401.

44 D. T. Shindell, G. Faluvegi, D. M. Koch, G. A. Schmidt, N. Unger and S. E. Bauer, Science, 2009, 326, 716-718.

45 D. T. Shindell, G. Faluvegi, N. Bell and G. A. Schmidt, Geophys. Res. Lett., 2005, 32, L04803.

46 J. J. West, A. M. Fiore, V. Naik, L. W. Horowitz, M. D. Schwarzkopf and D. L. Mauzerall, Geophys. Res. Lett., 2007, 34, L06806.

47 D. O'Donnell, K. Tsigaridis and J. Feichter, Atmos. Chem. Phys., $2011, \mathbf{1 1}, 8635-8659$.

48 A. Guenther, T. Karl, P. Harley, C. Wiedinmyer, P. Palmer and C. Geron, Atmos. Chem. Phys., 2006, 6, 3181-3210.

49 R. Atkinson and J. Arey, Atmos. Environ., 2003, 37(Suppl 2), 197-219.

50 NRC, Rethinking the ozone problem in rural and regional air pollution, National Academy Press, Washington, DC, 1991.

51 S. Sillman, in Handbook of Weather, Climate and Water, ed. T. Potter and C. BR, Wiley and Sons, Inc., 2003, pp. 227-242.

52 P. J. Valdes, D. J. Beerling and C. E. Johnson, Geophys. Res. Lett., 2005, 32, L02704.

53 J. Lelieveld, T. M. Butler, J. N. Crowley, T. J. Dillon, H. Fischer, L. Ganzeveld, H. Harder, M. G. Lawrence, M. Martinez, D. Taraborrelli and J. Williams, Nature, 2008, 452, 737-740.

54 D. Taraborrelli, M. G. Lawrence, J. N. Crowley, T. J. Dillon, S. Gromov, C. B. M. Grosz, L. Vereecken and J. Lelieveld, Nat. Geosci., 2012, 5, 190-193.

55 M. Prather, M. Gauss, T. Berntsen, I. Isaksen, J. Sundet, I. Bey, G. Brasseur, F. Dentener, R. Derwent, D. Stevenson, L. Grenfell, D. Hauglustaine, L. Horowitz, D. Jacob, L. Mickley, M. Lawrence, R. von Kuhlmann, J.-F. Muller, G. Pitari, H. Rogers, M. Johnson, J. Pyle, K. Law, M. van Weele and O. Wild, Geophys. Res. Lett., 2003, 30, 1100.

56 P. Crutzen, Pure Appl. Geophys., 1973, 106, 1385-1399.

57 D. S. Stevenson, F. J. Dentener, M. G. Schultz, K. Ellingsen, T. P. C. van Noije, O. Wild, G. Zeng, M. Amann, C. S. Atherton, N. Bell, D. J. Bergmann, I. Bey, T. Butler, J. Cofala, W. J. Collins, R. G. Derwent, R. M. Doherty, J. Drevet, H. J. Eskes, A. M. Fiore, M. Gauss, D. A. Hauglustaine, L. W. Horowitz, I. S. A. Isaksen, M. C. Krol, J. F. Lamarque, M. G. Lawrence, V. Montanaro, J. F. Müller, G. Pitari, M. J. Prather, J. A. Pyle, S. Rast, J. M. Rodriguez, M. G. Sanderson, N. H. Savage, D. T. Shindell, S. E. Strahan, K. Sudo and S. Szopa, J. Geophys. Res., 2006, 111, D08301.

58 A. M. Fiore, J. J. West, L. W. Horowitz, V. Naik and M. D. Schwarzkopf, J. Geophys. Res., 2008, 113, D08307.

59 J. J. West, A. M. Fiore and L. W. Horowitz, Clim. Change, 2012, DOI: $10.1007 / \mathrm{s} 10584-012-0426-4$.

60 K. L. Denman, G. Brasseur, A. Chidthaisong, P. Ciais, P. M. Cox, R. E. Dickinson, D. Hauglustaine, C. Heinze, E. Holland, D. Jacob, U. Lohmann, S. Ramachandran, P. L. da Silva Dias, S. C. Wofsy and X. Zhang, in Climate Change 2007: The Physical Science Basis. Contribution of Working Group I to the Fourth Assessment Report of the Intergovernmental Panel on Climate Change, ed. D. Qin, M. Manning, Z. Chen, M. Marquis, K. B. Averyt, M. Tignor and H. L. Miller, Cambridge University Press, Cambridge, United Kingdom and New York, NY, USA, 2007.

61 E. J. Dlugokencky, L. Bruhwiler, J. W. C. White, L. K. Emmons, P. C. Novelli, S. A. Montzka, K. A. Masarie, P. M. Lang, A. M. Crotwell, J. B. Miller and L. V. Gatti, Geophys. Res. Lett., 2009, 36, L18803.

62 F. M. Kai, S. C. Tyler, J. T. Randerson and D. R. Blake, Nature, 2011, 476, 194-197.

63 M. Aydin, K. R. Verhulst, E. S. Saltzman, M. O. Battle, S. A. Montzka, D. R. Blake, Q. Tang and M. J. Prather, Nature, 2011, 476, 198-201.

64 I. Mahlstein and R. Knutti, J. Geophys. Res., 2012, 117, D06104.

65 A. M. Fiore, F. J. Dentener, O. Wild, C. Cuvelier, M. G. Schultz, P. Hess, C. Textor, M. Schulz, R. M. Doherty, L. W. Horowitz, I. A. MacKenzie, M. G. Sanderson, D. T. Shindell, D. S. Stevenson, S. Szopa, R. Van Dingenen, G. Zeng, C. Atherton, D. Bergmann, I. Bey, G. Carmichael,
W. J. Collins, B. N. Duncan, G. Faluvegi, G. Folberth, M. Gauss, S. Gong, D. Hauglustaine, T. Holloway, I. S. A. Isaksen, D. J. Jacob, J. E. Jonson, J. W. Kaminski, T. J. Keating, A. Lupu, E. Marmer, V. Montanaro, R. J. Park, G. Pitari, K. J. Pringle, J. A. Pyle, S. Schroeder, M. G. Vivanco, P. Wind, G. Wojcik, S. Wu and A. Zuber, J. Geophys. Res., 2009, 114, D04301

66 O. Wild, A. M. Fiore, D. T. Shindell, R. M. Doherty, W. J. Collins, F. J. Dentener, M. G. Schultz, S. Gong, I. A. MacKenzie, G. Zeng, P. Hess, B. N. Duncan, D. J. Bergmann, S. Szopa, J. E. Jonson, T. J. Keating and A. Zuber, Atmos. Chem. Phys., 2012, 12, 2037-2054.

67 S. C. Anenberg, J. J. West, A. M. Fiore, D. A. Jaffe, M. J. Prather, D. Bergmann, K. Cuvelier, F. J. Dentener, B. N. Duncan, M. Gauss, P. Hess, J. E. Jonson, A. Lupu, I. A. MacKenzie, E. Marmer, R. J. Park, M. G. Sanderson, M. Schultz, D. T. Shindell, S. Szopa, M. G. Vivanco, O. Wild and G. Zeng, Environ. Sci. Technol., 2009, 43, 6482-6487.

68 J. J. West, A. M. Fiore, L. W. Horowitz and D. L. Mauzerall, Proc. Natl. Acad. Sci. U. S. A., 2006, 103, 3988-3993.

69 J. J. West and A. M. Fiore, Environ. Sci. Technol., 2005, 39, 4685-4691.

70 J. Haywood and O. Boucher, Rev. Geophys., 2000, 38, 513-543.

71 U. Lohmann and J. Feichter, Atmos. Chem. Phys., 2005, 5, 715-737.

72 D. Koch and A. D. Del Genio, Atmos. Chem. Phys., 2010, 10, 7685-7696.

73 M. Z. Jacobson, J. Geophys. Res., 2012, 117, D06205.

74 N. Mahowald, Science, 2011, 334, 794-796.

75 G. Myhre, T. F. Berglen, M. Johnsrud, C. R. Hoyle, T. K. Berntsen, S. A. Christopher, D. W. Fahey, I. S. A. Isaksen, T. A. Jones, R. A. Kahn, N. Loeb, P. Quinn, L. Remer, J. P. Schwarz and K. E. Yttri, Atmos. Chem. Phys., 2009, 9, 1365-1392.

76 N. Bellouin, A. Jones, J. Haywood and S. A. Christopher, J. Geophys. Res., 2008, 113, D10205.

77 G. Myhre, Science, 2009, 325, 187-190.

78 M. Schulz, C. Textor, S. Kinne, Y. Balkanski, S. Bauer, T. Berntsen, T. Berglen, O. Boucher, F. Dentener, S. Guibert, I. S. A. Isaksen, T. Iversen, D. Koch, A. Kirkevåg, X. Liu, V. Montanaro, G. Myhre, J. E. Penner, G. Pitari, S. Reddy, Ø. Seland, P. Stier and T. Takemura, Atmos. Chem. Phys., 2006, 6, 5225-5246.

79 C. E. Chung, V. Ramanathan, D. Kim and I. A. Podgorny, J. Geophys. Res., 2005, 110, D24207.

80 V. Ramanathan and G. Carmichael, Nat. Geosci., 2008, 1, 221-227.

81 D. Koch, M. Schulz, S. Kinne, C. McNaughton, J. R. Spackman, Y. Balkanski, S. Bauer, T. Berntsen, T. C. Bond, O. Boucher, M. Chin, A. Clarke, N. De Luca, F. Dentener, T. Diehl, O. Dubovik, R. Easter, D. W. Fahey, J. Feichter, D. Fillmore, S. Freitag, S. Ghan, P. Ginoux, S. Gong, L. Horowitz, T. Iversen, A. Kirkevåg, Z. Klimont, Y. Kondo, M. Krol, X. Liu, R. Miller, V. Montanaro, N. Moteki, G. Myhre, J. E. Penner, J. Perlwitz, G. Pitari, S. Reddy, L. Sahu, H. Sakamoto, G. Schuster, J. P. Schwarz, ò. Seland, P. Stier, N. Takegawa, T. Takemura, C. Textor, J. A. van Aardenne and Y. Zhao, Atmos. Chem. Phys., 2009, 9, 9001-9026.

82 C. C. Chuang, J. E. Penner, J. M. Prospero, K. E. Grant, G. H. Rau and K. Kawamoto, J. Geophys. Res., 2002, 107, 4564.

83 J. Quaas, O. Boucher, N. Bellouin and S. Kinne, J. Geophys. Res., 2008, 113, D05204.

84 J. Quaas, Y. Ming, S. Menon, T. Takemura, M. Wang, J. E. Penner, A. Gettelman, U. Lohmann, N. Bellouin, O. Boucher, A. M. Sayer, G. E. Thomas, A. McComiskey, G. Feingold, C. Hoose, J. E. Kristjánsson, X. Liu, Y. Balkanski, L. J. Donner, P. A. Ginoux, P. Stier, B. Grandey, J. Feichter, I. Sednev, S. E. Bauer, D. Koch, R. G. Grainger, A. Kirkevåg, T. Iversen, Ø. Seland, R. Easter, S. J. Ghan, P. J. Rasch, H. Morrison, J. F. Lamarque, M. J. Iacono, S. Kinne and M. Schulz, Atmos. Chem. Phys., 2009, 9, 8697-8717.

85 U. Lohmann, J. Feichter, J. Penner and R. Leaitch, J. Geophys. Res., 2000, 105, 12193-12206.

86 W. T. Chen, Y. H. Lee, P. J. Adams, A. Nenes and J. H. Seinfeld, Geophys. Res. Lett., 2010, 37, L09801. 
87 D. Koch, Y. Balkanski, S. E. Bauer, R. C. Easter, S. Ferrachat, S. J. Ghan, C. Hoose, T. Iversen, A. Kirkevåg, J. E. Kristjansson, X. Liu, U. Lohmann, S. Menon, J. Quaas, M. Schulz, Ø. Seland, T. Takemura and N. Yan, Atmos. Chem. Phys., 2011, 11, 1051-1064.

88 D. V. Spracklen, K. S. Carslaw, U. Pöschl, A. Rap and P. M. Forster, Atmos. Chem. Phys., 2011, 11, 9067-9087.

89 S. E. Bauer, S. Menon, D. Koch, T. C. Bond and K. Tsigaridis, Atmos. Chem. Phys., 2010, 10, 7439-7456.

90 J. Hansen and L. Nazarenko, Proc. Natl. Acad. Sci. U. S. A., 2004, 101, 423-428.

91 M. G. Flanner, C. S. Zender, J. T. Randerson and P. J. Rasch, J. Geophys. Res., 2007, 112, D11202.

92 M. Z. Jacobson, J. Geophys. Res., 2004, 109, D21201.

93 M. O. Andreae, C. D. Jones and P. M. Cox, Nature, 2005, 435, $1187-1190$

94 M. R. Allen, P. A. Stott, J. F. B. Mitchell, R. Schnur and T. L. Delworth, Nature, 2000, 407, 617-620.

95 V. Ramanathan and Y. Feng, Atmos. Environ., 2009, 43, 37-50.

96 A. Arneth, N. Unger, M. Kulmala and M. O. Andreae, Science, 2009, 326, 672-673.

97 G. P. Brasseur and E. Roeckner, Geophys. Res. Lett., 2005, 32, L23704.

98 S. Kloster, F. Dentener, J. Feichter, F. Raes, U. Lohmann, E. Roeckner and I. Fischer-Bruns, Clim. Dyn., 2010, 34, 1177-1194.

99 M. Z. Jacobson, J. Geophys. Res., 2002, 107, 4410.

100 T. C. Bond and H. Sun, Environ. Sci. Technol., 2005, 39, 5921-5926.

101 P. K. Quinn, T. S. Bates, E. Baum, N. Doubleday, A. M. Fiore, M. Flanner, A. Fridlind, T. J. Garrett, D. Koch, S. Menon, D. Shindell, A. Stohl and S. G. Warren, Atmos. Chem. Phys., 2008, 8, 1723-1735.

102 M. V. Ramana, V. Ramanathan, Y. Feng, S. C. Yoon, S. W. Kim, G. R. Carmichael and J. J. Schauer, Nat. Geosci., 2010, 3, 542-545.

103 K. Rypdal, N. Rive, T. K. Berntsen, Z. Klimont, T. K. Mideksa, G. Myhre and R. B. Skeie, Tellus, Ser. B, 2009, 61, 625-641.

104 A. P. Grieshop, C. C. O. Reynolds, M. Kandlikar and H. Dowlatabadi, Nat. Geosci., 2009, 2, 533-534.

105 T. C. Bond, Environ. Res. Lett., 2007, 2, 045030.

106 M. Jacobson, J. Geophys. Res., [Atmos.], 2010, D14209.

107 M. G. Flanner, C. S. Zender, P. G. Hess, N. M. Mahowald, T. H. Painter, V. Ramanathan and P. J. Rasch, Atmos. Chem. Phys., 2009, 9, 2481-2497.

108 E. M. Leibensperger, L. J. Mickley, D. J. Jacob, W. T. Chen, J. H. Seinfeld, A. Nenes, P. J. Adams, D. G. Streets, N. Kumar and D. Rind, Atmos. Chem. Phys., 2012, 12, 3349-3362.

109 E. M. Leibensperger, L. J. Mickley, D. J. Jacob, W. T. Chen, J. H. Seinfeld, A. Nenes, P. J. Adams, D. G. Streets, N. Kumar and D. Rind, Atmos. Chem. Phys., 2012, 12, 3333-3348.

110 M. Yoshimori and A. J. Broccoli, J. Clim., 2008, 21, 4399-4423.

111 D. Shindell and G. Faluvegi, Nat. Geosci., 2009, 2, 294-300.

112 L. J. Mickley, E. M. Leibensperger, D. J. Jacob and D. Rind, Atmos. Environ., 2012, 46, 545-553.

113 P. Ceppi, S. C. Scherrer, A. M. Fischer and C. Appenzeller, Int. J. Clim., 2012, 32, 203-213, DOI: 10.1002/joc.2260.

114 G. J. van Oldenborgh, S. Drijfhout, A. van Ulden, R. Haarsma, A. Sterl, C. Severijns, W. Hazeleger and H. Dijkstra, Clim. Past, $2009,5,1-12$

115 G. J. van Oldenborgh, P. Yiou and R. Vautard, Atmos. Chem. Phys., 2010, 10, 4597-4609.

116 R. Allen and S. Sherwood, Clim. Dyn., 2010, 1-20.

117 M. A. Bollasina, Y. Ming and V. Ramaswamy, Science, 2011, 334, 502-505.

118 Y. Ming and V. Ramaswamy, J. Clim., 2011, 24, 5125-5133.

119 Y. Ming, V. Ramaswamy and G. Chen, J. Clim., 2011, 24, 6077-6091.

120 H. Kawase, T. Takemura and T. Nozawa, J. Geophys. Res., 2011, 116, D18116.

121 G. A. Meehl, J. M. Arblaster and W. D. Collins, J. Clim., 2008, 21, 2869-2882.

122 Y. Ming, V. Ramaswamy and G. Persad, Geophys. Res. Lett., 2010, 37, L13701.

123 L. Ott, B. Duncan, S. Pawson, P. Colarco, M. Chin, C. Randles, T. Diehl and E. Nielsen, J. Geophys. Res., 2010, 115, D14121.
124 C. A. Randles and V. Ramaswamy, Atmos. Chem. Phys., 2010, 10, 9819-9831.

125 C. Wang, D. Kim, A. M. L. Ekman, M. C. Barth and P. J. Rasch, Geophys. Res. Lett., 2009, 36, L21704.

126 S. Menon, J. Hansen, L. Nazarenko and Y. Luo, Science, 2002, 297, 2250-2253.

127 M. Biasutti and A. Giannini, Geophys. Res. Lett., 2006, 33, L11706.

128 E. Roeckner, P. Stier, J. Feichter, S. Kloster, M. Esch and I. Fischer-Bruns, Clim. Dyn., 2006, 27, 553-571.

129 P. O'Gorman, R. Allan, M. Byrne and M. Previdi, Surv. Geophys., 2011, 1-24.

130 C. Textor, M. Schulz, S. Guibert, S. Kinne, Y. Balkanski, S. Bauer, T. Berntsen, T. Berglen, O. Boucher, M. Chin, F. Dentener, T. Diehl, R. Easter, H. Feichter, D. Fillmore, S. Ghan, P. Ginoux, S. Gong, A. Grini, J. Hendricks, L. Horowitz, P. Huang, I. Isaksen, I. Iversen, S. Kloster, D. Koch, A. Kirkevåg, J. E. Kristjansson, M. Krol, A. Lauer, J. F. Lamarque, X. Liu, V. Montanaro, G. Myhre, J. Penner, G. Pitari, S. Reddy, Ø. Seland, P. Stier, T. Takemura and X. Tie, Atmos. Chem. Phys., 2006, 6, 1777-1813.

131 D. T. Shindell, A. Voulgarakis, G. Faluvegi and G. Milly, Atmos. Chem. Phys. Discuss., 2012, 12, 5015-5037.

132 A. G. Carlton, C. Wiedinmyer and J. H. Kroll, Atmos. Chem. Phys., 2009, 9, 4987-5005.

133 B. Ervens, B. J. Turpin and R. J. Weber, Atmos. Chem. Phys., 2011, 11, 11069-11102.

134 M. Hallquist, J. C. Wenger, U. Baltensperger, Y. Rudich, D. Simpson, M. Claeys, J. Dommen, N. M. Donahue, C. George, A. H. Goldstein, J. F. Hamilton, H. Herrmann, T. Hoffmann, Y. Iinuma, M. Jang, M. E. Jenkin, J. L. Jimenez, A. Kiendler-Scharr, W. Maenhaut, G. McFiggans, T. F. Mentel, A. Monod, A. S. H. Prévôt, J. H. Seinfeld, J. D. Surratt, R. Szmigielski and J. Wildt, Atmos. Chem. Phys., 2009, 9, 5155-5236.

135 E. L. Shapiro, J. Szprengiel, N. Sareen, C. N. Jen, M. R. Giordano and V. F. McNeill, Atmos. Chem. Phys., 2009, 9, 2289-2300.

136 A. H. Goldstein, C. D. Koven, C. L. Heald and I. Y. Fung, Proc. Natl. Acad. Sci. U. S. A., 2009, 106, 8835-8840.

137 C. R. Hoyle, G. Myhre, T. K. Berntsen and I. S. A. Isaksen, Atmos. Chem. Phys., 2009, 9, 2715-2728.

138 R. J. Weber, A. P. Sullivan, R. E. Peltier, A. Russell, B. Yan, M. Zheng, J. de Gouw, C. Warneke, C. Brock, J. S. Holloway, E. L. Atlas and E. Edgerton, J. Geophys. Res., [Atmos.], 2007, $112,13$.

139 R. Y. Zhang, L. Wang, A. F. Khalizov, J. Zhao, J. Zheng, R. L. McGraw and L. T. Molina, Proc. Natl. Acad. Sci. U. S. A., 2009, 106, 17650-17654.

140 C. R. Hoyle, M. Boy, N. M. Donahue, J. L. Fry, M. Galsius, A. Guenther, A. G. Hallar, K. Huff Hartz, M. Petters, T. Petaja, T. Rosenoern and A. P. Sullivan, Atmos. Chem. Phys., 2011, 11, 321-343.

141 A. G. Carlton, R. W. Pinder, P. V. Bhave and G. A. Pouliot, Environ. Sci. Technol., 2010, 44, 3376-3380.

142 D. V. Spracklen, J. L. Jimenez, K. S. Carslaw, D. R. Worsnop, M. J. Evans, G. W. Mann, Q. Zhang, M. R. Canagaratna, J. Allan, H. Coe, G. McFiggans, A. Rap and P. Forster, Atmos. Chem. Phys., 2011, 11, 12109-12136.

143 C. L. Heald, H. Coe, J. L. Jimenez, R. J. Weber, R. Bahreini, A. M. Middlebrook, L. M. Russell, M. Jolleys, T. M. Fu, J. D. Allan, K. N. Bower, G. Capes, J. Crosier, W. T. Morgan, N. H. Robinson, P. I. Williams, M. J. Cubison, P. F. DeCarlo and E. J. Dunlea, Atmos. Chem. Phys., 2011, 11, 12673-12696.

144 K. Tsigaridis, M. Krol, F. J. Dentener, Y. Balkanski, J. Lathière, S. Metzger, D. A. Hauglustaine and M. Kanakidou, Atmos. Chem. Phys., 2006, 6, 5143-5162.

145 T. E. Lane, N. M. Donahue and S. N. Pandis, Atmos. Environ., 2008, 42, 7439-7451.

146 Y. Balkanski, G. Myhre, M. Gauss, G. Radel, E. J. Highwood and K. P. Shine, Atmos. Chem. Phys., 2010, 10, 4477-4489.

147 J. Fuglestvedt and T. Berntsen, Proc. Natl. Acad. Sci. U. S. A., 2008, 105, 19154-19159.

148 J. Fuglestvedt, T. Berntsen, G. Myhre, K. Rypdal and R. B. Skeie, Proc. Natl. Acad. Sci. U. S. A., 2008, 105, 454-458. 
149 P. Hoor, J. Borken-Kleefeld, D. Caro, O. Dessens, O. Endresen, M. Gauss, V. Grewe, D. Hauglustaine, I. S. A. Isaksen, P. Jockel, J. Lelieveld, G. Myhre, E. Meijer, D. Olivie, M. Prather, C. S. Poberaj, K. P. Shine, J. Staehelin, Q. Tang, J. van Aardenne, P. van Velthoven and R. Sausen, Atmos. Chem. Phys., 2009, 9, 3113-3136.

150 D. S. Lee, D. W. Fahey, P. M. Forster, P. J. Newton, R. C. N. Wit, L. L. Lim, B. Owen and R. Sausen, Atmos. Environ., 2009, 43, 3520-3537.

151 D. S. Lee, G. Pitari, V. Grewe, K. Gierens, J. E. Penner, A. Petzold, M. J. Prather, U. Schumann, A. Bais, T. Berntsen, D. Iachetti, L. L. Lim and R. Sausen, Atmos. Environ., 2010, 44, 4678-4734.

152 D. S. Stevenson and R. G. Derwent, Geophys. Res. Lett., 2009 36, L17810.

153 G. Myhre, K. P. Shine, G. Rädel, M. Gauss, I. S. A. Isaksen, Q. Tang, M. J. Prather, J. E. Williams, P. van Velthoven, O. Dessens, B. Koffi, S. Szopa, P. Hoor, V. Grewe, J. BorkenKleefeld, T. K. Berntsen and J. S. Fuglestvedt, Atmos. Environ., 2011, 45, 387-394.

154 E. Uherek, T. Halenka, J. Borken-Kleefeld, Y. Balkanski, T. Berntsen, C. Borrego, M. Gauss, P. Hoor, K. Juda-Rezler, J. Lelieveld, D. Melas, K. Rypdal and S. Schmid, Atmos. Environ., 2010, 44, 4772-4816.

155 V. Eyring, I. S. A. Isaksen, T. Berntsen, W. J. Collins, J. J. Corbett, O. Endresen, R. G. Grainger, J. Moldanova, H. Schlager and D. S. Stevenson, Atmos. Environ., 2010, 44, 4735-4771.

156 K. Odemark, S. B. Dalsoren, B. H. Samset, T. K. Berntsen, J. S. Fuglestvedt and G. Myhre, Atmos. Chem. Phys., 2012, 12, 1979-1993.

157 M. Z. Jacobson, J. Clim., 2004, 17, 2909-2926.

158 V. Naik, D. L. Mauzerall, L. W. Horowitz, M. D. Schwarzkopf, V. Ramaswamy and M. Oppenheimer, Geophys. Res. Lett., 2007, 34, L03818.

159 N. Unger, D. T. Shindell and J. S. Wang, Atmos. Environ., 2009, 43, 3077-3085.

160 D. Shindell and G. Faluvegi, Atmos. Chem. Phys., 2010, 10, 3247-3260.

161 K. Aunan, T. K. Berntsen, G. Myhre, K. Rypdal, D. G. Streets, J. H. Woo and K. R. Smith, Atmos. Environ., 2009, 43, 5674-5681

162 N. Unger, D. T. Shindell, D. M. Koch and D. G. Streets, J. Geophys. Res., 2008, 113, D02306.

163 D. Shindell, J. F. Lamarque, N. Unger, D. Koch, G. Faluvegi, S. Bauer, M. Ammann, J. Cofala and H. Teich, Atmos. Chem. Phys., 2008, 8, 7101-7113.

164 D. Koch, T. C. Bond, D. Streets, N. Unger and G. R. van der Werf, J. Geophys. Res., 2007, 112, D02205.

165 N. Unger, T. C. Bond, J. S. Wang, D. M. Koch, S. Menon, D. T. Shindell and S. Bauer, Proc. Natl. Acad. Sci. U. S. A., 2010, 107, 3382-3387.

166 J. Fuglestvedt, T. Berntsen, V. Eyring, I. Isaksen, D. S. Lee and R. Sausen, Environ. Sci. Technol., 2009, 43, 9057-9062.

167 D. A. Lack and J. J. Corbett, Atmos. Chem. Phys., 2012, 12, 3985-4000

168 D. Shindell, G. Faluvegi, M. Walsh, S. C. Anenberg, R. Van Dingenen, N. Z. Muller, J. Austin, D. Koch and G. Milly, Nat. Clim. Change, 2011, 1, 59-66.

169 M. Z. Jacobson, Environ. Sci. Technol., 2007, 41, 4150-4157.

170 A. Lauer, V. Eyring, J. J. Corbett, C. Wang and J. J. Winebrake, Environ. Sci. Technol., 2009, 43, 5592-5598.

171 M. Righi, C. Klinger, V. Eyring, J. Hendricks, A. Lauer and A. Petzold, Environ. Sci. Technol., 2011, 45, 3519-3525.

172 M. G. Schultz, T. Diehl, G. P. Brasseur and W. Zittel, Science, 2003, 302, 624-627.

173 B. van Ruijven, J.-F. Lamarque, D. P. van Vuuren, T. Kram and H. Eerens, Global Environ. Change, 2011, 21, 983-994.

174 A. P. Grieshop, J. D. Marshall and M. Kandlikar, Energy Policy, 2011, 39, 7530-7542.

175 B. Felzer, D. Kicklighter, J. Melillo, C. Wang, Q. Zhuang and R. Prinn, Tellus, Ser. B: Chem. Phys. Meteorol., 2004, 56, 230-248.

176 G. D. Farquhar and M. L. Roderick, Science, 2003, 299, 1997-1998.

177 M. L. Roderick, G. D. Farquhar, S. L. Berry and I. R. Noble, Oecologia, 2001, 129, 21-30.
178 L. M. Mercado, N. Bellouin, S. Sitch, O. Boucher, C. Huntingford, M. Wild and P. M. Cox, Nature, 2009, 458, U1014-U1087.

179 A. Knohl and D. D. Baldocchi, J. Geophys. Res., 2008, 113, G02023.

180 D. Niyogi, H.-I. Chang, V. K. Saxena, T. Holt, K. Alapaty, F. Booker, F. Chen, K. J. Davis, B. Holben, T. Matsui, T. Meyers, W. C. Oechel, R. A. Pielke Sr., R. Wells, K. Wilson and Y. Xue, Geophys. Res. Lett., 2004, 31, L20506.

181 J. C. Péré, M. Mallet, V. Pont and B. Bessagnet, J. Geophys. Res., 2011, 116, D23119.

182 Y. Huang, W. L. Chameides and R. E. Dickinson, J. Geophys. Res., 2007, 112, D03212.

183 K. S. Carslaw, O. Boucher, D. V. Spracklen, G. W. Mann, J. G. L. Rae, S. Woodward and M. Kulmala, Atmos. Chem. Phys., 2010, 10, 1701-1737.

184 M. Kulmala, T. Suni, K. E. J. Lehtinen, M. Dal Maso, M. Boy, A. Reissell, ú. Rannik, P. Aalto, P. Keronen, H. Hakola, J. Bäck, T. Hoffmann, T. Vesala and P. Hari, Atmos. Chem. Phys., 2004, 4, $557-562$.

185 P. Meir, P. Cox and J. Grace, Trends Ecol. Evol., 2006, 21, 254-260.

186 J. Avise, J. Chen, B. Lamb, C. Wiedinmyer, A. Guenther, E. Salathé and C. Mass, Atmos. Chem. Phys., 2009, 9, 1111-1124.

187 C. L. Heald, D. K. Henze, L. W. Horowitz, J. Feddema, J. F. Lamarque, A. Guenther, P. G. Hess, F. Vitt, J. H. Seinfeld, A. H. Goldstein and I. Fung, J. Geophys. Res., 2008, 113, D05211.

188 S. Wu, L. J. Mickley, J. O. Kaplan and D. J. Jacob, Atmos. Chem. Phys., 2012, 12, 1597-1609.

189 J. Chen, J. Avise, A. Guenther, C. Wiedinmyer, E. Salathé, R. B. Jackson and B. Lamb, Atmos. Environ., 2009, 43, 5771-5780.

190 A. P. K. Tai, L. J. Mickley, D. J. Jacob, E. M. Leibensperger, L. Zhang, J. A. Fisher and H. O. T. Pye, Atmos. Chem. Phys., 2012, 12, 3131-3145.

191 T. Appelhans, A. Sturman and P. Zawar-Reza, Int. J. Climatol., 2012, DOI: $10.1002 /$ joc. 3439 .

192 J. A. Logan, J. Geophys. Res., 1989, 94, 8511-8532.

193 C. Ordóñez, N. Elguindi, O. Stein, V. Huijnen, J. Flemming, A. Inness, H. Flentje, E. Katragkou, P. Moinat, V. H. Peuch, A. Segers, V. Thouret, G. Athier, M. van Weele, C. S. Zerefos, J. P. Cammas and M. G. Schultz, Atmos. Chem. Phys., 2010, 10, 789-815.

194 A. P. K. Tai, L. J. Mickley and D. J. Jacob, Atmos. Environ., 2010, 44, 3976-3984.

195 E. M. Leibensperger, L. J. Mickley and D. J. Jacob, Atmos. Chem. Phys., 2008, 8, 7075-7086.

196 R. Vautard, C. Honoré, M. Beekmann and L. Rouil, Atmos. Environ., 2005, 39, 2957-2967.

197 M. Vieno, A. J. Dore, D. S. Stevenson, R. Doherty, M. R. Heal, S. Reis, S. Hallsworth, L. Tarrason, P. Wind, D. Fowler, D. Simpson and M. A. Sutton, Atmos. Chem. Phys., 2010, 10, 7963-7978.

198 F. M. Vukovich, Atmos. Environ., 1995, 29, 2259-2273.

199 C. Andersson and M. Engardt, J. Geophys. Res., 2010, 115, D02303

200 D. Jaffe, D. Chand, W. Hafner, A. Westerling and D. Spracklen, Environ. Sci. Technol., 2008, 42, 5885-5891.

201 D. Jaffe, W. Hafner, D. Chand, A. Westerling and D. Spracklen, Environ. Sci. Technol., 2008, 42, 2812-2818.

202 X. Jiang, Z.-L. Yang, H. Liao and C. Wiedinmyer, Atmos. Environ., 2010, 44, 4891-4907.

203 T. D. Jickells, Z. S. An, K. K. Andersen, A. R. Baker, G. Bergametti, N. Brooks, J. J. Cao, P. W. Boyd, R. A. Duce, K. A. Hunter, H. Kawahata, N. Kubilay, J. laRoche, P. S. Liss, N. Mahowald, J. M. Prospero, A. J. Ridgwell, I. Tegen and R. Torres, Science, 2005, 308, 67-71.

204 D. V. Spracklen, L. J. Mickley, J. A. Logan, R. C. Hudman, R. Yevich, M. D. Flannigan and A. L. Westerling, J. Geophys. Res., 2009, 114, D20301.

205 A. L. Steiner, A. J. Davis, S. Sillman, R. C. Owen, A. M. Michalak and A. M. Fiore, Proc. Natl. Acad. Sci. U. S. A., 2010, DOI: $10.1073 /$ pnas.1008336107.

206 M. Engardt, R. Bergstrom and C. Andersson, Ambio, 2009, 38, $452-458$. 
207 A. L. Steiner, S. Tonse, R. C. Cohen, A. H. Goldstein and R. A. Harley, J. Geophys. Res., 2006, 111, D18303.

208 J. P. Dawson, P. J. Adams and S. N. Pandis, Atmos. Environ., 2007, 41, 1494-1511.

209 A. Mahmud, M. Tyree, D. Cayan, N. Motallebi and M. J. Kleeman, J. Geophys. Res., 2008, 113, D21103.

210 A. P. K. Tai, L. J. Mickley and D. J. Jacob, Atmos. Chem. Phys. Discuss., 2012, 12, 18107-18131.

211 T. Holloway, S. N. Spak, D. Barker, M. Bretl, C. Moberg, K. Hayhoe, J. Van Dorn and D. Wuebbles, J. Geophys. Res., 2008, 113, D22306.

212 L. J. Donner, B. L. Wyman, R. S. Hemler, L. W. Horowitz, Y. Ming, M. Zhao, J.-C. Golaz, P. Ginoux, S. J. Lin, M. D. Schwarzkopf, J. Austin, G. Alaka, W. F. Cooke, T. L. Delworth, S. M. Freidenreich, C. T. Gordon, S. M. Griffies, I. M. Held, W. J. Hurlin, S. A. Klein, T. R. Knutson, A. R. Langenhorst, H.-C. Lee, Y. Lin, B. I. Magi, S. L. Malyshev, P. C. D. Milly, V. Naik, M. J. Nath, R. Pincus, J. J. Ploshay, V. Ramaswamy, C. J. Seman, E. Shevliakova, J. J. Sirutis, W. F. Stern, R. J. Stouffer, R. J. Wilson, M. Winton, A. T. Wittenberg and F. Zeng, J. Clim., 2011, 24, 3484-3519.

213 D. T. Shindell, G. Faluvegi, N. Unger, E. Aguilar, G. A. Schmidt, D. M. Koch, S. E. Bauer and R. L. Miller, Atmos. Chem. Phys., 2006, 6, 4427-4459.

214 L. Pozzoli, I. Bey, S. Rast, M. G. Schultz, P. Stier and J. Feichter, J. Geophys. Res., 2008, 113, D07308.

215 A. Shalaby, A. S. Zakey, A. B. Tawfik, F. Solmon, F. Giorgi, F. Stordal, S. Sillman, R. A. Zaveri and A. L. Steiner, Geosci. Model Dev., 2012, 5, 741-760.

216 C. Knote, D. Brunner, H. Vogel, J. Allan, A. Asmi, M. Äijälä, S. Carbone, H. D. van der Gon, J. L. Jimenez, A. KiendlerScharr, C. Mohr, L. Poulain, A. S. H. Prévot, E. Swietlicki and B. Vogel, Geosci. Model Dev., 2011, 4, 1077-1102.

217 Y. Zhang, X. Y. Wen and C. J. Jang, Atmos. Environ., 2010, 44, $3568-3582$

218 M. Jacobson, Y. Kaufman and Y. Rudich, J. Geophys. Res., [Atmos.], 2007, 112, D24205.

219 A. Mahmud, M. Hixson, J. Hu, Z. Zhao, S. H. Chen and M. J. Kleeman, Atmos. Chem. Phys., 2010, 10, 11097-11114.

220 C. Hogrefe, B. Lynn, K. Civerolo, J. Y. Ku, J. Rosenthal, C. Rosenzweig, R. Goldberg, S. Gaffin, K. Knowlton and P. L. Kinney, J. Geophys. Res., 2004, 109, D22301.

221 K. Murazaki and P. Hess, J. Geophys. Res., 2006, 111, D05301.

222 J. P. Dawson, P. N. Racherla, B. H. Lynn, P. J. Adams and S. N. Pandis, J. Geophys. Res., 2009, 114, D05308.

223 C. G. Nolte, A. B. Gilliland, C. Hogrefe and L. J. Mickley, J. Geophys. Res., 2008, 113, D14307.

224 R. Forkel and R. Knoche, J. Geophys. Res., 2006, 111, D12302.

225 E. Katragkou, P. Zanis, I. Tegoulias, D. Melas, I. Kioutsioukis, B. C. Krüger, P. Huszar, T. Halenka and S. Rauscher, Atmos. Chem. Phys., 2010, 10, 11805-11821.

226 D. J. Rasmussen, A. M. Fiore, V. Naik, L. W. Horowitz, S. J. McGinnis and M. G. Schultz, Atmos. Environ., 2012, 47, $142-153$.

227 K. G. Thishan Dharshana, S. Kravtsov and J. D. W. Kahl, J. Geophys. Res., 2010, 115, D24219.

228 M. Z. Jacobson, Geophys. Res. Lett., 2008, 35, L03809.

229 A. Carvalho, A. Monteiro, M. Flannigan, S. Solman, A. I. Miranda and C. Borrego, Atmos. Environ., 2011, 45, 5545-5553.

230 L. J. Mickley, D. J. Jacob, B. D. Field and D. Rind, Geophys. Res. Lett., 2004, 31, L24103.

231 C. Ordóñez, H. Mathis, M. Furger, S. Henne, C. Hüglin, J. Staehelin and A. S. H. Prévôt, Atmos. Chem. Phys., 2005, 5, $1187-1203$.

232 R. M. Doherty, D. T. Shindell, G. Zeng, O. Wild, W. J. Collins, D. S. Stevenson, I. A. MacKenzie, A. M. Fiore, F. J. Dentener, P. Hess, M. Schultz, R. G. Derwent and T. J. Keating, J. Geophys. Res. [Atmos.], 2012, submitted.

233 NRC, Global Sources of Local Pollution: An Assessment of LongRange Transport of Key Air Pollutants to and from the United States, The National Academies Press, 2009.

234 C. E. Johnson, W. J. Collins, D. S. Stevenson and R. G. Derwent, J. Geophys. Res., 1999, 104, 18631-18645.
235 M. I. Hegglin and T. G. Shepherd, Nat. Geosci., 2009, 2, 687-691.

236 H. Kawase, T. Nagashima, K. Sudo and T. Nozawa, Geophys. Res. Lett., 2011, 38, L05801.

237 G. Zeng, J. A. Pyle and P. J. Young, Atmos. Chem. Phys., 2008, 8, 369-387.

238 G. Zeng, O. Morgenstern, P. Braesicke and J. A. Pyle, Geophys. Res. Lett., 2010, 37, L09805.

239 S. Wu, L. J. Mickley, D. J. Jacob, D. Rind and D. G. Streets, J. Geophys. Res., 2008, 113, D18312.

240 F. Dentener, D. Stevenson, K. Ellingsen, T. van Noije, M. Schultz, M. Amann, C. Atherton, N. Bell, D. Bergmann, I. Bey, L. Bouwman, T. Butler, J. Cofala, B. Collins, J. Drevet, R. Doherty, B. Eickhout, H. Eskes, A. Fiore, M. Gauss, D. Hauglustaine, L. Horowitz, I. S. A. Isaksen, B. Josse, M. Lawrence, M. Krol, J. F. Lamarque, V. Montanaro, J. F. Müller, V. H. Peuch, G. Pitari, J. Pyle, S. Rast, J. Rodriguez, M. Sanderson, N. H. Savage, D. Shindell, S. Strahan, S. Szopa, K. Sudo, R. Van Dingenen, O. Wild and G. Zeng, Environ. Sci. Technol., 2006, 40, 3586-3594.

241 H. O. T. Pye, H. Liao, S. Wu, L. J. Mickley, D. J. Jacob, D. K. Henze and J. H. Seinfeld, J. Geophys. Res., 2009, 114, D01205.

242 P. N. Racherla and P. J. Adams, J. Geophys. Res., 2006, 111, D24103.

243 K.-J. Liao, E. Tagaris, K. Manomaiphiboon, S. L. Napelenok, J.-H. Woo, S. He, P. Amar and A. G. Russell, Environ. Sci. Technol., 2007, 41, 8355-8361.

244 E. Tagaris, K. Manomaiphiboon, K.-J. Liao, L. R. Leung, J.-H. Woo, S. He, P. Amar and A. G. Russell, J. Geophys. Res., 2007, 112, D14312.

245 Y. Zhang, X.-M. Hu, L. R. Leung and W. I. Gustafson Jr., J. Geophys. Res., 2008, 113, D18310.

246 D. Stevenson, R. Doherty, M. Sanderson, C. Johnson, B. Collins and D. Derwent, Faraday Discuss., 2005, 130, 41-57.

247 Y. Fang, A. M. Fiore, L. W. Horowitz, A. Gnanadesikan, I. Held, G. Chen, G. Vecchi and H. Levy, J. Geophys. Res., 2011, 116, D18303.

248 M. J. Kleeman, Clim. Change, 2008, 87(Suppl 1), S273-S292.

249 N. M. Mahowald and C. Luo, Geophys. Res. Lett., 2003, 30, 1903.

250 I. Tegen, M. Werner, S. P. Harrison and K. E. Kohfeld, Geophys. Res. Lett., 2004, 31, L05105.

251 N. M. Mahowald, Geophys. Res. Lett., 2007, 34, L18817.

252 N. M. Mahowald, D. R. Muhs, S. Levis, P. J. Rasch, M. Yoshioka, C. S. Zender and C. Luo, J. Geophys. Res., 2006, 111, D10202.

253 S. Woodward, D. L. Roberts and R. A. Betts, Geophys. Res. Lett., 2005, 32, L18810.

254 M. D. Flannigan, M. A. Krawchuk, W. J. de Groot, B. M. Wotton and L. M. Gowman, Int. J. Wildland Fire, 2009, 18, 483-507.

255 J. M. Prospero, J. Geophys. Res., 1999, 104, 15917-15927.

256 F. E. Grousset, P. Ginoux, A. Bory and P. E. Biscaye, Geophys. Res. Lett., 2003, 30, 1277.

257 H.-C. Huang, J. Lin, Z. Tao, H. Choi, K. Patten, K. Kunkel, M. Xu, J. Zhu, X.-Z. Liang, A. Williams, M. Caughey, D. J. Wuebbles and J. Wang, J. Geophys. Res., 2008, 113, D19307.

258 M. Chin, T. Diehl, P. Ginoux and W. Malm, Atmos. Chem. Phys., 2007, 7, 5501-5517.

259 S. E. Bauer and D. Koch, J. Geophys. Res., 2005, 110, D17202.

260 N. Meskhidze, W. L. Chameides, A. Nenes and G. Chen, Geophys. Res. Lett., 2003, 30, 2085.

261 A. Nenes, M. D. Krom, N. Mihalopoulos, P. Van Cappellen, Z. Shi, A. Bougiatioti, P. Zarmpas and B. Herut, Atmos. Chem. Phys., 2011, 11, 6265-6272.

262 P. A. Ginoux, J. M. Prospero, T. E. Gill, C. Hsu and M. Zhao, Rev. Geophys., 2012, DOI: 10.1029/2012RG000388.

263 H. Bauer, A. Kasper-Giebl, M. Loflund, H. Giebl, R. Hitzenberger, F. Zibuschka and H. Puxbaum, Atmos. Res., 2002, 65, 109-119.

264 C. L. Heald and D. V. Spracklen, Geophys. Res. Lett., 2009, 36, L09806.

265 S. M. Burrows, T. Butler, P. Jöckel, H. Tost, A. Kerkweg, U. Pöschl and M. G. Lawrence, Atmos. Chem. Phys., 2009, 9, 9281-9297.

266 G. B. Hedegaard, J. Brandt, J. H. Christensen, L. M. Frohn, C. Geels, K. M. Hansen and M. Stendel, Atmos. Chem. Phys., 2008, 8, 3337-3367. 
267 N. Unger, D. T. Shindell, D. M. Koch, M. Amann, J. Cofala and D. G. Streets, J. Geophys. Res., 2006, 111, D12313.

268 H. Liao, W.-T. Chen and J. H. Seinfeld, J. Geophys. Res., 2006, 111, D12304.

269 J. Aw and M. J. Kleeman, J. Geophys. Res., 2003, 108, 4365.

270 M. C. Day and S. N. Pandis, Atmos. Environ., 2011, 45, 6546-6556.

271 S. C. Farina, P. J. Adams and S. N. Pandis, J. Geophys. Res., 2010, 115, D09202.

272 E. M. Leibensperger, L. J. Mickley, D. J. Jacob and S. R. H. Barrett, Atmos. Environ., 2011, 45, 3318-3324.

273 J. Liu, D. L. Mauzerall, L. W. Horowitz, P. Ginoux and A. M. Fiore, Atmos. Environ., 2009, 43, 4327-4338.

274 M. Tressol, C. Ordonez, R. Zbinden, J. Brioude, V. Thouret, C. Mari, P. Nedelec, J. P. Cammas, H. Smit, H. W. Patz and A. Volz-Thomas, Atmos. Chem. Phys., 2008, 8, 2133-2150.

275 R. T. Clark, J. M. Murphy and S. J. Brown, Geophys. Res. Lett., 2010, 37, L17703.

276 N. S. Diffenbaugh and M. Ashfaq, Geophys. Res. Lett., 2010, 37, L15701.

277 P. A. Stott, D. A. Stone and M. R. Allen, Nature, 2004, 432, 610-614.

278 Royal Society, Ground-level ozone in the 21st century: future trends, impacts and policy implications ISBN: 978-0-85403-713-1, 2008.

279 X. Jiang, C. Wiedinmyer, F. Chen, Z.-L. Yang and J. C.-F. Lo, J. Geophys. Res., 2008, 113, D20312.

280 J. Chen, J. Avise, B. Lamb, E. Salathé, C. Mass, A. Guenther, C. Wiedinmyer, J. F. Lamarque, S. O'Neill, D. McKenzie and N. Larkin, Atmos. Chem. Phys., 2009, 9, 1125-1141.

281 J. Langner, M. Engardt and C. Andersson, Atmos. Chem. Phys. Discuss., 2012, 12, 7705-7726.

282 P. N. Racherla and P. J. Adams, Atmos. Chem. Phys., 2008, 8, $871-885$.

283 S. Szopa, D. A. Hauglustaine, R. Vautard and L. Menut, Geophys. Res. Lett., 2006, 33, L14805.

284 H. Liao, Y. Zhang, W.-T. Chen, F. Raes and J. H. Seinfeld, J. Geophys. Res., 2009, 114, D10306.

285 F. Meleux, F. Solmon and F. Giorgi, Atmos. Environ., 2007, 41, $7577-7587$.

286 P. N. Racherla and P. J. Adams, Environ. Sci. Technol., 2008, 43, 571-577.

287 E. Katragkou, P. Zanis, I. Kioutsioukis, I. Tegoulias, D. Melas, B. C. Krüger and E. Coppola, J. Geophys. Res., 2011, 116, D22307.

288 T. M. Butler, Z. S. Stock, M. R. Russo, H. A. C Denier van der Gon and M. G. Lawrence, Atmos. Chem. Phys., 2012, 12, 4413-4428.

289 K. E. Taylor, R. J. Stouffer and G. A. Meehl, Bull. Am. Meteorol. Soc., 2011, 93, 485-498.

290 IPCC, Appendix II in Climate Change 2001. The Scientific Basis, Cambridge University Press, Cambridge, United Kingdom and New York, NY, USA, 2001.

291 K. Yamaji, T. Ohara, I. Uno, J.-I. Kurokawa, P. Pochanart and H. Akimoto, J. Geophys. Res., 2008, 113, D08306.

292 L. Ganzeveld, L. Bouwman, E. Stehfest, D. P. van Vuuren, B. Eickhout and J. Lelieveld, J. Geophys. Res., 2010, 115, D23301.

293 C. Granier, U. Niemeier, J. H. Jungclaus, L. Emmons, P. Hess, J.-F. Lamarque, S. Walters and G. P. Brasseur, Geophys. Res. Lett., 2006, 33, L13807.

294 B. Collins, M. G. Sanderson and C. E. Johnson, Meteorol. Z., 2009, 18, 25-39.

295 N. Bellouin, J. Rae, A. Jones, C. Johnson, J. Haywood and O. Boucher, J. Geophys. Res., 2011, 116, D20206.

296 K. J. Liao, E. Tagaris, K. Manomaiphiboon, C. Wang, J. H. Woo, P. Amar, S. He and A. G. Russell, Atmos. Chem. Phys., 2009, 9, 865-878.

297 E. Tagaris, K. J. Liao, K. Manomaiphiboon, S. He, J. H. Woo, P. Amar and A. G. Russell, Atmos. Chem. Phys., 2008, 8, 3973-3983.

298 J. Kelly, P. A. Makar and D. A. Plummer, Atmos. Chem. Phys. Discuss., 2012, 12, 3875-3940.

299 G. R. Carmichael, B. Adhikary, S. Kulkarni, A. D'Allura, Y. Tang, D. Streets, Q. Zhang, T. C. Bond, V. Ramanathan, A. Jamroensan and P. Marrapu, Environ. Sci. Technol., 2009, 43, $5811-5817$
300 Y. F. Lam, J. S. Fu, S. Wu and L. J. Mickley, Atmos. Chem. Phys., 2011, 11, 4789-4806.

301 S. E. Bauer, D. Koch, N. Unger, S. M. Metzger, D. T. Shindell and D. G. Streets, Atmos. Chem. Phys., 2007, 7, 5043-5059.

302 R. V. Martin, B. Sauvage, I. Folkins, C. E. Sioris, C. Boone, P. Bernath and J. Ziemke, J. Geophys. Res., 2007, 112, D09309.

303 A. Richter, J. P. Burrows, H. Nusz, C. Granier and U. Niemeier, Nature, 2005, 437, 129-132.

304 Y. Choi, Y. Wang, T. Zeng, D. Cunnold, E.-S. Yang, R. Martin, K. Chance, V. Thouret and E. Edgerton, J. Geophys. Res., 2008 , 113, D20311.

305 A. K. Mebust, A. R. Russell, R. C. Hudman, L. C. Valin and R. C. Cohen, Atmos. Chem. Phys., 2011, 11, 5839-5851.

306 A. R. Russell, A. E. Perring, L. C. Valin, E. J. Bucsela, E. C. Browne, P. J. Wooldridge and R. C. Cohen, Atmos. Chem. Phys., 2011, 11, 8543-8554.

307 P. Castellanos and K. F. Boersma, Sci. Rep., 2012, 2, 265.

308 S. Beirle, K. F. Boersma, U. Platt, M. G. Lawrence and T. Wagner, Science, 2011, 333, 1737-1739.

309 M. J. Prather, J. E. Penner, J. S. Fuglestvedt, A. Kurosawa, J. A. Lowe, N. Höhne, A. K. Jain, N. Andronova, L. Pinguelli, C. Pires de Campos, S. C. B. Raper, R. B. Skeie, P. A. Stott, J. van Aardenne and F. Wagner, Geophys. Res. Lett., 2009, 36, L05707.

310 M. J. Prather, C. D. Holmes and J. Hsu, Geophys. Res. Lett., 2012, 39, L09803.

311 C. Y. C. Lin, D. J. Jacob and A. M. Fiore, Atmos. Environ., 2001, 35, 3217-3228.

312 B. W. LaFranchi, A. H. Goldstein and R. C. Cohen, Atmos. Chem. Phys., 2011, 11, 6945-6960.

313 B. J. Bloomer, J. W. Stehr, C. A. Piety, R. J. Salawitch and R. R. Dickerson, Geophys. Res. Lett., 2009, 36, L09803.

314 B. J. Bloomer, K. Y. Vinnikov and R. R. Dickerson, Atmos. Environ., 2010, 44, 2543-2551.

315 A. M. Aghedo, K. W. Bowman, H. M. Worden, S. S. Kulawik, D. T. Shindell, J. F. Lamarque, G. Faluvegi, M. Parrington, D. B. A. Jones and S. Rast, J. Geophys. Res., 2011, 116, D01305.

316 H. M. Worden, K. W. Bowman, S. S. Kulawik and A. M. Aghedo, J. Geophys. Res., 2011, 116, D14115.

317 V. Eyring, N. R. P. Harris, M. Rex, T. G. Shepherd, D. W. Fahey, G. T. Amanatidis, J. Austin, M. P. Chipperfield, M. Dameris, P. M. D. F. Forster, A. Gettelman, H. F. Graf, T. Nagashima, P. A. Newman, S. Pawson, M. J. Prather, J. A. Pyle, R. J. Salawitch, B. D. Santer and D. W. Waugh, Bull. Am. Meteorol. Soc., 2005, 86, 1117-1133.

318 D. W. Waugh and V. Eyring, Atmos. Chem. Phys., 2008, 8, 5699-5713.

319 SPARC and CCMVal, Report on the Evaluation of ChemistryClimate Models 5, 2010.

320 S. Wu, L. J. Mickley, D. J. Jacob, J. A. Logan, R. M. Yantosca and D. Rind, J. Geophys. Res., 2007, 112, D05302.

321 A. T. Archibald, M. C. Cooke, S. R. Utembe, D. E. Shallcross, R. G. Derwent and M. E. Jenkin, Atmos. Chem. Phys., 2010, 10, 8097-8118.

322 F. Paulot, J. D. Crounse, H. G. Kjaergaard, J. H. Kroll, J. H. Seinfeld and P. O. Wennberg, Atmos. Chem. Phys., 2009, 9, 1479-1501.

323 A. M. Fiore, L. W. Horowitz, D. W. Purves, H. Levy II., M. J. Evans, Y. Wang, Q. Li and R. M. Yantosca, J. Geophys. Res., 2005, 110, D12303.

324 L. W. Horowitz, A. M. Fiore, G. P. Milly, R. C. Cohen, A. Perring, P. J. Wooldridge, P. G. Hess, L. K. Emmons and J.-F. Lamarque, J. Geophys. Res., 2007, 112, D12S08.

325 A. Ito, S. Sillman and J. E. Penner, J. Geophys. Res., 2009, 114, D09301.

326 A. T. Archibald, J. G. Levine, N. L. Abraham, M. C. Cooke, P. M. Edwards, D. E. Heard, M. E. Jenkin, A. Karunaharan, R. C. Pike, P. S. Monks, D. E. Shallcross, P. J. Telford, L. K. Whalley and J. A. Pyle, Geophys. Res. Lett., 2011, 38, L05804.

327 A. E. Perring, T. H. Bertram, P. J. Wooldridge, A. Fried, B. G. Heikes, J. Dibb, J. D. Crounse, P. O. Wennberg, N. J. Blake, D. R. Blake, W. H. Brune, H. B. Singh and R. C. Cohen, Atmos. Chem. Phys., 2009, 9, 1451-1463.

328 A. L. Lockwood, P. B. Shepson, M. N. Fiddler and M. Alaghmand, Atmos. Chem. Phys., 2010, 10, 6169-6178. 
329 F. Paulot, J. D. Crounse, H. G. Kjaergaard, A. Kürten, J. M. St. Clair, J. H. Seinfeld and P. O. Wennberg, Science, 2009, 325, 730-733.

330 X. Yang, R. A. Cox, N. J. Warwick, J. A. Pyle, G. D. Carver, F. M. O'Connor and N. H. Savage, J. Geophys. Res., 2005, 110, D23311.

331 L. K. Whalley, K. L. Furneaux, A. Goddard, J. D. Lee, A. Mahajan, H. Oetjen, K. A. Read, N. Kaaden, L. J. Carpenter, A. C. Lewis, J. M. C. Plane, E. S. Saltzman, A. Wiedensohler and D. E. Heard, Atmos. Chem. Phys., 2010, 10, 1555-1576.

332 B. D. Finley and E. S. Saltzman, J. Geophys. Res., 2008, 113, D21301.

333 K. A. Read, A. S. Mahajan, L. J. Carpenter, M. J. Evans, B. V. E. Faria, D. E. Heard, J. R. Hopkins, J. D. Lee, S. J. Moller, A. C. Lewis, L. Mendes, J. B. McQuaid, H. Oetjen, A. Saiz-Lopez, M. J. Pilling and J. M. C. Plane, Nature, 2008, 453, 1232-1235.

334 A. Saiz-Lopez, J. F. Lamarque, D. E. Kinnison, S. Tilmes, C. Ordóñez, J. J. Orlando, A. J. Conley, J. M. C. Plane, A. S. Mahajan, G. Sousa Santos, E. L. Atlas, D. R. Blake, S. P. Sander, S. Schauffler, A. M. Thompson and G. Brasseur, Atmos. Chem. Phys., 2012, 12, 3939-3949.

335 J. P. Parrella, D. J. Jacob, Q. Liang, Y. Zhang, L. J. Mickley, B. Miller, M. J. Evans, X. Yang, J. A. Pyle, N. Theys and M. Van Roozendael, Atmos. Chem. Phys. Discuss., 2012, 12, 9665-9715.

336 L. A. Lee, K. S. Carslaw, K. J. Pringle, G. W. Mann and D. V. Spracklen, Atmos. Chem. Phys., 2011, 11, 12253-12273.

337 X.-Z. Liang, J. Pan, J. Zhu, K. E. Kunkel, J. X. L. Wang and A. Dai, J. Geophys. Res., 2006, 111, D10108.

338 D. J. L. Olivié, D. Cariolle, H. Teyssèdre, D. Salas, A. Voldoire, H. Clark, D. Saint-Martin, M. Michou, F. Karcher, Y. Balkanski, M. Gauss, O. Dessens, B. Koffi and R. Sausen, Atmos. Chem. Phys., 2012, 12, 1449-1480.

339 H. Levy II., M. D. Schwarzkopf, L. Horowitz, V. Ramaswamy and K. L. Findell, J. Geophys. Res., 2008, 113, D06102.

340 D. T. Shindell, H. Levy II., M. D. Schwarzkopf, L. W. Horowitz, J.-F. Lamarque and G. Faluvegi, J. Geophys. Res., 2008, 113, D11109.

341 G. B. Boer and B. Y. Yu, Clim. Dyn., 2003, 20, 415-429.

342 D. Shindell, M. Schulz, Y. Ming, T. Takemura, G. Faluvegi and V. Ramaswamy, J. Geophys. Res., 2010, 115, D19110.

343 M. Trainer, E. J. Williams, D. D. Parrish, M. P. Buhr, E. J. Allwine, H. H. Westberg, F. C. Fehsenfeld and S. C. Liu, Nature, 1987, 329, 705-707.

344 C. Wiedinmyer, X. Tie, A. Guenther, R. Neilson and C. Granier, Earth Interact., 2006, 10, 1-19.
345 D. W. Purves, J. P. Caspersen, P. R. Moorcroft, G. C. Hurtt and S. W. Pacala, Global Change Biol., 2004, 10, 1737-1755.

346 R. K. Monson, N. Trahan, T. N. Rosenstiel, P. Veres, D. Moore, M. Wilkinson, R. J. Norby, A. Volder, M. G. Tjoelker, D. D. Briske, D. F. Karnosky and R. Fall, Philoso. Trans. R. Soc., A, 2007, 365, 1677-1695.

347 I. Fung, J. John, J. Lerner, E. Matthews, M. Prather, L. P. Steele and P. J. Fraser, J. Geophys. Res., 1991, 96, 13033-13065.

348 R. W. Pinder, P. J. Adams, S. N. Pandis and A. B. Gilliland, J. Geophys. Res., 2006, 111, D16310.

349 A. Arneth, Ü. Niinemets, S. Pressley, J. Bäck, P. Hari, T. Karl, S. Noe, I. C. Prentice, D. Serça, T. Hickler, A. Wolf and B. Smith, Atmos. Chem. Phys., 2007, 7, 31-53.

350 F. Pacifico, S. P. Harrison, C. D. Jones and S. Sitch, Atmos. Environ., 2009, 43, 6121-6135.

351 D. A. Jaffe and N. L. Wigder, Atmos. Environ., 2012, 51, 1-10.

352 D. V. Spracklen, J. A. Logan, L. J. Mickley, R. J. Park, R. Yevich, A. L. Westerling and D. A. Jaffe, Geophys. Res. Lett., 2007, 34, L16816.

353 M. Cao, K. Gregson and S. Marshall, Atmos. Environ., 1998, 32, 3293-3299.

354 R. V. Martin, D. J. Jacob, J. A. Logan, I. Bey, R. M. Yantosca, A. C. Staudt, Q. Li, A. M. Fiore, B. N. Duncan, H. Liu, P. Ginoux and V. Thouret, J. Geophys. Res., 2002, 107, 4351.

355 H. Bian and C. S. Zender, J. Geophys. Res., 2003, 108, 4672.

356 S. E. Bauer, Y. Balkanski, M. Schulz, D. A. Hauglustaine and F. Dentener, J. Geophys. Res., 2004, 109, D02304.

357 O. Wild, Atmos. Chem. Phys., 2007, 7, 2643-2660.

358 U. Schumann and H. Huntrieser, Atmos. Chem. Phys., 2007, 7, 3823-3907.

359 L. J. Labrador, R. von Kuhlmann and M. G. Lawrence, Atmos. Chem. Phys., 2005, 5, 1815-1834.

360 C. Lang and D. W. Waugh, J. Geophys. Res., 2011, 116, D04103.

361 I. Barmpadimos, C. Hueglin, J. Keller, S. Henne and A. S. H. Prévôt, Atmos. Chem. Phys., 2011, 11, 1813-1835.

362 J. Hansen, M. Sato, R. Ruedy, K. Lo, D. W. Lea and M. MedinaElizade, Proc. Natl. Acad. Sci. U. S. A., 2006, 103, 14288-14293.

363 E. Tagaris, K.-J. Liao, A. J. DeLucia, L. Deck, P. Amar and A. G. Russell, Environ. Sci. Technol., 2009, 43, 4979-4988.

364 TF HTAP, Task Force on Hemispheric Transport of Air Pollution 2007 Interim Report, United Nations Economic Commission for Europe, New York and Geneva, 2007.

365 TF HTAP, Hemispheric Transport of Air Pollution 2010 Part A: Ozone And Particulate Matter, Air Pollution Studies No. 17, United Nations, New York, 2010. 